\title{
Molecular Approaches of Candidate Genes in Genetic Improvement Programs in Poultry
}

\author{
Khalil, M. H., Iraqi, M. M. and Saleh, M. S. \\ Department of Animal Production, Faculty of Agriculture at Moshtohor, Benha University, Egypt \\ Corresponding author email: maher.khalil@ fagr.bu.edu.eg
}

\begin{abstract}
In poultry, selection programs through quantitative genetics are time consuming in case of lowly heritable traits. Several genes that to be used in selection are regarded as candidate genes that affecting economic traits in poultry and these candidate genes have successful approaches in identifying several DNA markers associated with production and reproductive traits. Candidate genes are one of the primary methods to determine the specific genes related to the economic traits and molecular genetics techniques can be used to identify these genes or their chromosomal regions in terms of Quantitative Trait Loci (QTL) that affect these traits. Using biotechnology techniques are the best way to achieve this fast genetic improvement. This approach has enabled opportunities to enhance genetic improvement programs in poultry by direct selection on genes or genomic regions that affect economic traits through marker-assisted selection (MAS) and gene introgression. Mapping of quantitative trait loci (QTL) was the perfect approach to identify genes related to complex traits at genome-wide level. Recently, genome wide association study (GWAS) was used to identify the casual genes affecting economic traits in poultry using sequences variations mainly single nucleotide polymorphism (SNP). Many genes for growth and egg production were identified in poultry using GWAS method. The objectives of this reviewed article are: 1) To apply a fine chromosomal mapping for localizing the QTL affecting economic traits in the $\mathrm{F}_{2}$ population using specific microsatellite markers or SNP's in chickens and possibly identify candidate genes and causative mutations associated with the economic traits, 2) Determining the molecular markers to be used for evaluating the genetic variability among poultry breeds, 3) Reporting and characterizing the candidate genes to be used in genetic improvement programs, 4) Detecting the molecular associations between candidate genes and growth, feeding and egg traits and disease resistance responses, 5) Determining the SNP genotypes and their associations with growth and feeding performances, egg traits and disease resistance responses, 6) Defining the genetic model for detecting the molecular associations between SNP genotypes of candidate gene and economic traits, 7) Performing genome wide association study (GWAS) in order to detect potential causative mutations and genomic regions affecting productive and reproductive traits in chickens, 8) Applying genomic selection program based on the estimated Genomic Breeding Values (GBV), and 9) Suggesting a genetic improvement program to improve the Egyptian chickens breeds and strains using molecular approaches.
\end{abstract}

Keywords: Poultry, Molecular applications, Candidate genes, GWAS, Genomic Breeding Values (GBV), Genomic selection.

The chromosomal QTL mapping and their positions in chicken genome:

The chicken genome consists of 38 pairs of autosomes and sex chromosomes $\mathrm{Z}$ and $\mathrm{W}$. The chromosomes can be classified into two size groups, nine macrochromosomes and 30 microchromosomes (Bloom et al., 1993). Recent development of statistical methods and comprehensive linkage maps of the chicken genome has provided tools for mapping loci affecting quantitative traits (Mackay et al., 2009). However, only few genome-wide QTL scans have been reported in poultry, and none of these has involved egg production and egg quality traits in layers.

The identification and utilization of QTL provide the potential for more rapid genetic improvement in selection programs, especially for traits that are difficult to be improved with traditional selection (Ikeobi et al., 2002). In the last 15 years, several experimental chicken populations $\left(\mathrm{F}_{0}, \mathrm{~F}_{1}, \mathrm{~F}_{2}\right.$ and $\left.\mathrm{F}_{3}\right)$ have been constructed from different breeds for use in gene and QTL mapping studies (Jacobsson, 2005; Liu et al., 2008; Bulut et al., 2013; Abdel A'al et al., 2016; 2017). To exemplify, the chromosomal regions affecting phenotypic traits (many growth and egg traits) in different chicken breeds have been investigated (Tatsuda and Fujinaka 2001; Sewalem et al., 2002; Li et al., 2003; Sasaki et al., 2004; Siwek et al., 2004; Nones et al., 2006; Nassar et al., 2013; Abdel A'al et al., 2016; 2017).

In Germany, Goraga et al. (2012) reported that: 1) A highly significant region on chromosome 4 with multiple QTL for egg production traits between 19.2 and $82.1 \mathrm{Mb}$, 2) QTL region explained 4.3 and $16.1 \%$ of the phenotypic variance for number of eggs and egg weight in the $\mathrm{F}_{2}$ population, respectively, 3) Genomewide suggestive QTL for egg weight were found on chromosomes 1,5 , and 9 , and for number of eggs on chromosomes 5 and 7, 4) A genome-wide significant QTL affecting age at first egg was mapped on chromosome 1. Nassar et al. $(2013,2015)$ found that CCKAR gene had specific effects on growth trait and fat deposition in white adipose tissues using quantitative trait loci (QTL) in a population crosses between New Hampshire and White Leghorn chickens.

In Egypt, the chromosomal map to be used for detecting growth and egg traits in $\mathrm{F}_{2}$ population are 
presented in Figure 1 as cited by Abdel A'al $\boldsymbol{e t}$ al. (2016). The linkage map consists of marker loci in an order on the chromosome and the map distance between the markers. The distances are given in centiMorgan (cM, one $\mathrm{cM}$ is equal to one recombination event in 100 meioses) and are calculated using one of the map functions. Abdel A'al et al. (2016) reported that: A total of 19 significant genome QTL that affected body weight traits were located on seven macro-chromosomes $(1,2,3,4,6,8$ and $\mathrm{Z}$ ) and one micro-chromosome (11), 2) A total of
14 significant QTL were detected for daily gain traits, distributed over 7 distinct regions on 6 chromosomes, and their effects ranged from 2 to $8.9 \%$ of the phenotypic variation, 3) A total of 11 significant genome QTL affecting daily gain traits were located on five macro-chromosomes (1, 2, 3, 4 and 8), 4) there was statistical evidence for two QTL on chromosome 4 , 5) The proportions of phenotypic variation explained by significant and suggestive QTL for body weight traits at 4,8,12 and 16 weeks were 21.1, 30.8, 29.3 and $25.4 \%$, respectively.

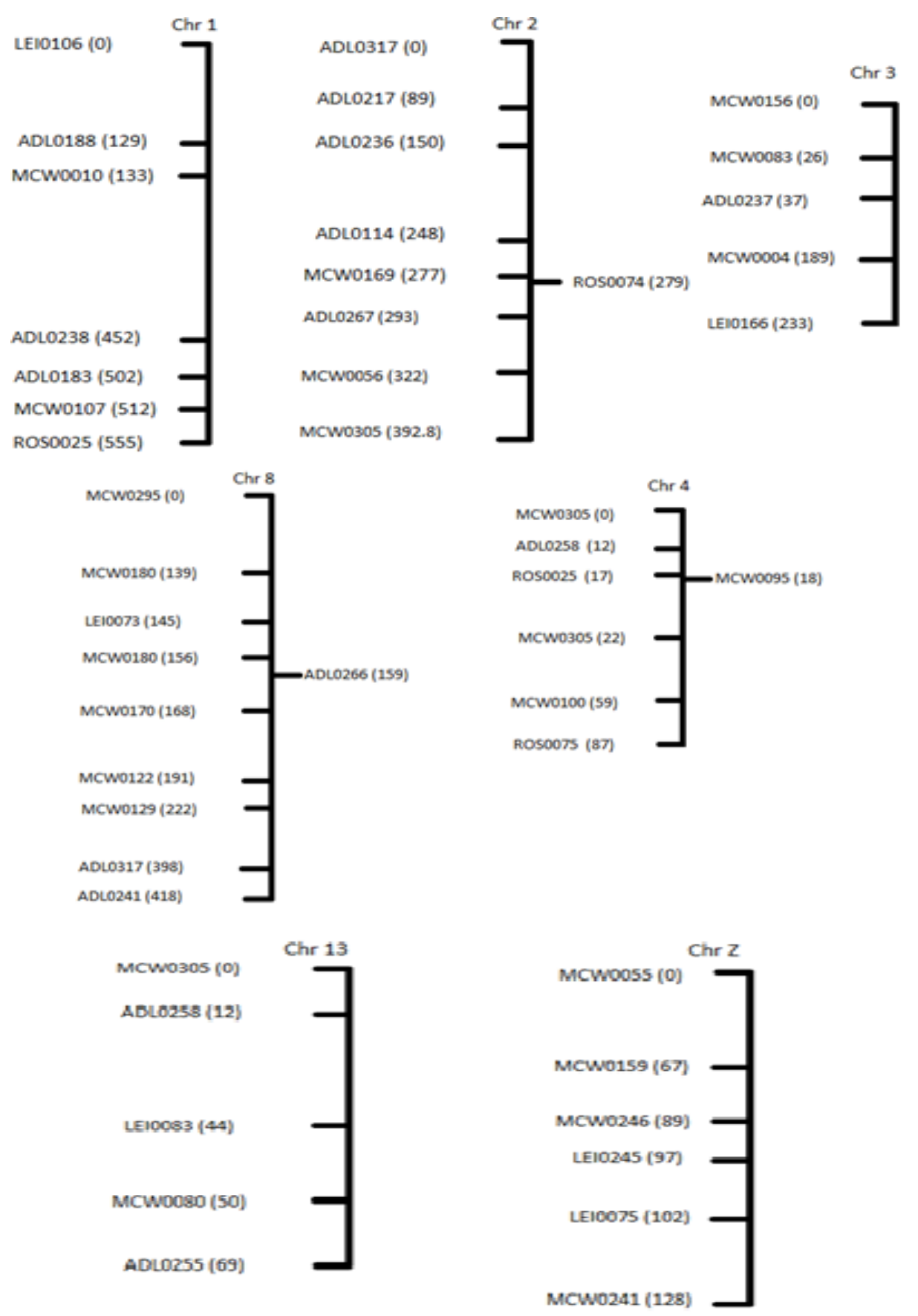

Figure 1. QTL mappings in chickens, including positions and names of the markers as cited by the Egyptian study (Abdel A'al et al., 2016). 
The estimates on the length of the complete genome ranged from 3064 to $3800 \mathrm{cM}$, based on the mapping function and the map distances covered 48 to $60 \%$ of the whole chicken genome. The markers MCW247 (on chromosome 2) and ADL345 (on chromosome 8) have been mapped only in the Wageningen reference population, while the marker MCW170 (on chromosome 4) and markers MCW133 and ADL315 (both on chromosome 7) and marker MCW129 (on chromosome 4) have been mapped only in the East Lansing population.

For QTL mapping and their positions detected for growth traits, Abdel A'al et al. (2016) illustrated that the chromosome group, number of informative microsatellite markers, chromosome map length $(c M)$, that was used for a whole genome scan of growth traits in $F_{2}$ cross are presented in Table 1. They reported that the total chromosomal map length was1901 cM ranging from $25 \mathrm{cM}$ on chromosome 11 to $568 \mathrm{cM}$ on chromosome 1 , with an average marker spacing of $24.39 \mathrm{cM}$ and that ranging from $7.8 \mathrm{cM}$ on chromosome 8 to $24.3 \mathrm{cM}$ on chromosome 1 . The position of QTL relative to the first marker (cM) indicated that QTL were located in the region of 0 to
$502 \mathrm{cM}, 0$ to $233 \mathrm{cM}, 0$ to $179 \mathrm{cM}$ and 12 to $555 \mathrm{cM}$ for body weights at $4,8,12$ and 16 weeks of age, respectively. He also cited that the total chromosomal map length for egg production and egg quality traits was $1949 \mathrm{cM}$ ranging from $52 \mathrm{cM}$ on chromosome 11 to $542 \mathrm{cM}$ on chromosome 1 , with an average marker spacing of $43.3 \mathrm{cM}$ and that ranging from $15.3 \mathrm{cM}$ on chromosome 4 to $71.5 \mathrm{cM}$ on chromosome 6 .

For QTL mapping and their positions detected for egg traits, previous work has suggested that chromosome 4 may be a critical region significantly associated with the variety of egg traits (Sewalem $\boldsymbol{e t}$ al., 2002; Tuiskula-Haavisto et al., 2002; Sasaki et al., 2004; Abdel A'al et al., 2016).

Khalil et al. (2016) concluded that: 1) QTL detected for body weight on chromosomes 1, 2, 3, 4, 6, 8, 11 and $\mathrm{Z}$ and those detected on chromosomes 2, 3, 4, 8 and $\mathrm{Z}$ for egg production and egg quality traits were significant and concluded that there are different sets of genes affecting early and late body weights and egg production and egg quality traits. It is not very easy at this moment to look for candidate genes in the regions with QTL and the most important reason is that the QTL regions are still too large.

Table 1. Chromosome (linkage) group, number of microsatellite markers and map length (cM), that was used for a whole genome scan of growth and egg traits in $\mathrm{F}_{2}$ cross

\begin{tabular}{|c|c|c|c|c|c|c|}
\hline \multirow[t]{2}{*}{ Chromosome } & \multicolumn{2}{|c|}{$\begin{array}{c}\text { Number of } \\
\text { microsatellite markers }\end{array}$} & \multicolumn{2}{|c|}{$\begin{array}{l}\text { Chromosome map } \\
\text { length }(\mathrm{cM})\end{array}$} & \multicolumn{2}{|c|}{$\begin{array}{l}\text { Average marker spacing by the } \\
\text { chromosome }(\mathrm{cM})\end{array}$} \\
\hline & Growth & Egg & Growth & Egg & Growth & Egg \\
\hline 1 & 10 & 9 & 568 & 542 & 24.3 & 60.2 \\
\hline 2 & 8 & 8 & 298 & 401 & 18.7 & 50.1 \\
\hline 3 & 2 & 6 & 273 & 144 & 11.6 & 24 \\
\hline 4 & 7 & 4 & 198 & 286 & 17.6 & 15.3 \\
\hline 6 & 4 & 3 & 111 & 123 & 10.4 & 71.5 \\
\hline 8 & 3 & 2 & 97 & 88 & 7.8 & 44 \\
\hline 9 & 1 & 2 & 123 & 112 & 20.1 & 56 \\
\hline 11 & 5 & 3 & 25 & 52 & 8.3 & 17.3 \\
\hline 13 & 2 & 2 & 71 & 69 & 14.5 & 34.5 \\
\hline $\mathrm{Z}$ & 5 & 6 & 137 & 132 & 11.5 & 22 \\
\hline Total & 47 & 45 & 1901 & 1949 & 14.48 & 43.3 \\
\hline
\end{tabular}

Source: Abdel A'al et al. (2016)

\section{Molecular markers to be used for evaluating the genetic variability:}

Molecular markers can be used to evaluate genetic variability, either within or among individuals, families, and populations. Genetic markers provide information as bioinformatics indicators about polymorphism in allelic frequency at a given locus. The availability of molecular markers in poultry allows the detailed analyses and evaluation of genetic diversity and furthermore the detection of genes influencing economically important traits. Molecular markers should not be considered as normal genes as they usually do not have any biological effect. They are identifiable DNA sequences, found in specific locations of the genome, and transmitted by inheritance from one generation to the next, allowing the assessment of genetic variability among genotypes at DNA level. In the last three decades, development of many fundamental DNA technologies such as sequencing, and PCR has helped in increasing the application of molecular markers (Weigend, 2004). The majority of molecular markers used nowadays are microsatellite markers, STRs (short tandem repeats) and SNPs (single nucleated polymorphism).

Among all types of the molecular markers, the microsatellites are used as the most widely markers for the analysis of genetic diversity and population structure in poultry (Erhardt and Weimann (2007). Nowadays, DNA molecular marker techniques are widely applied in the fields of germplasm 
identification, phylogenetic, and genetic structural analysis (Yang et al., 2013). Accordingly, the microsatellite has been used to develop the markers from genes and they have been referred as genic molecular markers (GMMs) or functional markers (FMs). Definite number of microsatellite markers covering nine autosomal linkage groups and the sex $\mathrm{Z}$ chromosome to be considered in genotyping $\mathrm{F}_{0}$ grandparents, $F_{1}$ and $F_{2}$ offspring. These markers were selected based on the degree of polymorphism and the genome coverage recommended in the molecular genetic characterization of animal genetic resources (FAO, 2011). Detailed information about selected microsatellites are available at the FAO website (www.dad.fao.org/en/

refer/library/guidelin/marker.pdf). The assessment of markers was based on their positions on the consensus map. A target for marker spacing of $10 \mathrm{cM}$ was used to test markers across the genome (http://www.ncbi.nlm.nih.gov/mapview and http://www.thearkdb.org).

Single Nucleotide Polymorphisms (SNPs) particularly interesting as markers was acquainted firstly by Lander (1996). As stated by Brown (1999), SNP as a marker has the following advantages over the other types of genetic markers: 1) It has high level of polymorphism, 2) It has distribution throughout the genome, 3) It has the presence within coding regions, 4) It has introns and regions that flank genes, 5) It is simple and unambiguous assay technique, 6) It has stable Mendelian inheritance, and 7) It has low levels of spontaneous mutation, (8) SNPs are less informative due to their biallelic nature, (9) SNPs have high-resolution in whole genome allelotyping because of their abundance, even spacing, and stability across the genome, and (10) SNP technique is used to identify the paternal and maternal alleles of a given gene based on polymorphisms. Genomic selection using the SNP markers is a powerful new tool for genetic selection and this is because: 1) SNPs can be detected by a number of techniques such as PCRRFLP, 2) SNP is relatively new technology using DNA chips that can be used for large scale screening of numerous samples in a minimal amount of time (Fontanesi et al., 2008), 3) SNP is the most recent contribution to study DNA sequence variation, and 4) SNP represents the most innovative molecular marker in genotyping studies. On the other hand, recent advances in high-throughput DNA sequencing, computer software and bioinformatics have been facilitated the identification of SNP. Kumar $\boldsymbol{e t}$ al. (2007) examined the genetic relationships among the indigenous chicken's populations in India using 10 genotyped SNP markers of the Myostatin gene (GDF8 ) by PCR-RFLP. Another application of SNPs in chickens was applied by Twito et al. (2007) who used 25 SNPs for different genes and chromosomes to examine the genetic relationships among 20 chicken populations using the STRUCTURE software program and they compared the SNP results with the analysis using microsatellites and concluded that: 1) Microsatellites provide high clustering success due to high polymorphic nature, 2) SNPs provide broader genome coverage and reliable estimates of genetic relatedness in the genome, and 3) SNP considered to be an efficient and cost-effective genetic tool.

\section{Molecular characterization of candidate genes in poultry breeds:}

The candidate genes in local poultry breeds must be characterized in terms of the following genetic parameters:

1) Allelic and genotypic frequencies to be calculated.

2) The genetic diversity of candidate genes to be assessed by calculating the effective number of alleles $(\mathrm{Ne})$, the observed $(\mathrm{Ho})$ and expected $(\mathrm{He})$ heterozygosity using GENALEX software, version 6.5 (Peakall and Smouse, 2012).

3) Hardy-Weinberg equilibrium (HWE) within each population to be estimated using GENEPOP program (Raymond, 1995); http://genepop.curtin.edu.au/) performing the Chisquare test for each genetic group studied.

4) The polymorphism information content (PIC) to be calculated using CERVUS software, version 3 (Kalinowski et al., 2007):

5) The F-statistics of the reduction in heterozygosity due to inbreeding within each population $\left(F_{I S}\right)$ to be calculated using GENEPOP software, version $3.4 \quad$ (Raymond, 1995); http://genepop.curtin.edu.au/).

\section{Molecular associations between candidate genes and growth and feeding traits:}

The associations' studies cited in Table 2 have been investigated to clarify the relationship between candidate genes and growth and feeding traits in poultry. The concept of these associations could be summarized as follows:

1) Genes located on chromosome 1: The Pituitary specific transcription factor-1 (Pit-1) (Jin et al., 2018), pituitary-specific positive transcription factor 1 (Nie et al., 2008), Thyroid hormone responsive spot $14 \alpha$ (Cao et al., 2007), Interferon$\gamma(I F N-\gamma)$ (Zhou et al., 2001; Ye et al., 2006; Ahmed, 2010, Inhibitor of apoptosis protein-1 (IAPI) (Liu and Lamont, 2003; Ye et al., 2006), Insulin-like growth factor (IGF1) (Amills et al., 2003; Wei et al., 2009),

2) Genes located on chromosome 2: Insulin-like growth factor (IGF2) (Amills et al., 2003), Insulinlike growth factor binding protein $(I G F B P) 1$ and 3 (Ye et al., 2006; Ou et al., 2009; Zhao et al., 2015), Accessory protein of the toll like receptor $4(M D-2)$ (Ye et al., 2006),

3) Genes located on chromosome 3: Ornithine decarboxylase $(O D C$ ) (Ye et al., 2006; Uemoto et al., 2011; Cahyadi et al., 2013), Gallinacins 2 to 5 (Gal 2 to Gal 5) (Saleh et al., 2020a; Saleh et al., 2020b), 
4) Genes located on chromosome 4: Cholecystokinin type A receptor (CCKAR) (Rikimaru et al., 2012; Yi et al., 2018), Interleukin-2 (IL-2) (Kramer et al., 2003; Ye et al., 2006; Kazemi et al., 2018), Tumor necrosis factor-related apoptosis-inducing ligand (TRAIL) (Ye et al., 2006), Bone morphogenetic protein receptor $1 \mathrm{~B}$ (BMPR-1B) (Niknafs et al., 2012; Ashraf and El-Tarabany, 2015),

5) Genes located on chromosome 5: Calpain 3 (Zhang et al., 2009), Transforming growth factor$\beta 3$ (TGF- $\beta 3$ ) (Ye et al., 2006), Insulin (INS) (Lei et al., 2007),

6) Genes located on chromosome 7: Insulin-like growth factor binding protein-2 (IGFBP-2) (Lei et al., 2005; Leng et al., 2009),

7) Genes located on chromosome 8: Leptin receptor gene (LEPR) (Park et al., 2006; El Moujahid et al., 2014)

8) Genes located on chromosome 9: Growth hormone secretagogue receptor (GHSR) (Fang et al., 2010),

9) Genes located on chromosome 10: Insulin-like growth factor 1 receptor (Lei et al., 2008),
10)Genes located on chromosome 15: Macrophage migration inhibitory factor (MIF) (Malek et al., 2004; Ye et al., 2006),

11)Genes located on chromosome 17: Toll-like receptor 4 (TLR4) (Malek et al., 2004),

12) Genes located on chromosome 19: Inducible nitric oxide synthase (iNOS) (Kramer et al., 2003; Ye et al., 2006); Caspase-1 (CASP1) (Liu and Lamont, 2003; Zhou and Lamont, 2003a; Ye $e t$ al., 2006),

13)Genes located on chromosome 20: Bone morphogenetic protein-7 (BMP7) (Ye et al., 2006) located on chromosome 21: PR domain containing 16 (PRDM16) (Cahyadi et al., 2013),

14) Genes located on chromosome 26: Thyroidstimulating hormone beta subunit $(T S H-\beta)$ (Lei et al., 2007; Seo et al., 2013),

15) Genes located on chromosome 27: chicken growth hormones $(G H)$ and $(G H 1)$ (Nie et al., 2005; Anh et al., 2015),

16)Genes located on chromosome Z: Growth hormone receptor (GHR) (Lei et al., 2007).

Table 2. Candidate genes associated with growth and feeding traits in poultry as cited in literature

\begin{tabular}{|c|c|c|c|c|}
\hline Chr* & Candidate gene & Trait & Breed & Reference \\
\hline 1 & $\begin{array}{l}\text { Pituitary-specific } \\
\text { transcription factor-1 } \\
\text { (Pit-1) }\end{array}$ & $\begin{array}{l}\text { Body weight, daily } \\
\text { gain, feed intake, } \\
\text { feed conversion. }\end{array}$ & $\begin{array}{l}\text { White Recessive Rock } \times \\
\text { Xinghua Chinese }\left(\mathrm{F}_{2}\right), \\
\text { Yellow meat type N202 } \\
\text { and N301 }\end{array}$ & $\begin{array}{l}\text { Nie et al. (2008) } \\
\text { Jin et al. (2018) }\end{array}$ \\
\hline 1 & $\begin{array}{l}\text { Thyroid hormone } \\
\text { responsive spot } 14 \alpha\end{array}$ & $\begin{array}{l}\text { Body weight, daily } \\
\text { gain. }\end{array}$ & $\begin{array}{l}\text { Broiler } \times \text { Local Chinese } \\
\left(\mathrm{F}_{2}\right)\end{array}$ & Cao et al. (2007) \\
\hline 1 & Interferon- $\gamma(\boldsymbol{I F N}-\boldsymbol{\gamma})$ & $\begin{array}{l}\text { Body weight, feed } \\
\text { conversion. }\end{array}$ & $\begin{array}{l}\text { Fayoumi } \times \text { White } \\
\text { Leghorn }\left(\mathrm{F}_{2}\right) \\
\text { Commercial broiler }\end{array}$ & $\begin{array}{l}\text { Ahmed (2010) } \\
\text { Ye et al. (2006) }\end{array}$ \\
\hline 1 & $\begin{array}{l}\text { Inhibitor of apoptosis } \\
\text { protein-1 (IAPI) }\end{array}$ & $\begin{array}{l}\text { Body weight, daily } \\
\text { gain, feed intake. }\end{array}$ & $\begin{array}{l}\text { Fayoumi and } 2 \text { MHC- } \\
\text { congenic Leghorn lines } \\
\text { (G-B1 and G-B2) } \\
\text { Commercial broiler }\end{array}$ & $\begin{array}{l}\text { Liu and Lamont, } \\
(2003) \\
\text { Ye et al. }(2006)\end{array}$ \\
\hline 1 & $\begin{array}{l}\text { Chicken-B-cell marker } \\
\text { (CHBб) }\end{array}$ & $\begin{array}{l}\text { Body weight, feed } \\
\text { conversion. }\end{array}$ & Commercial broiler & Ye et al. (2006) \\
\hline 1 & $\begin{array}{l}\text { Insulin-like growth } \\
\text { factor }(\boldsymbol{I G F 1 )}\end{array}$ & $\begin{array}{l}\text { Body weight, daily } \\
\text { gain, feed intake. }\end{array}$ & $\begin{array}{l}\text { Black Penedesenca (PN } \\
\text { and MN) }\end{array}$ & $\begin{array}{l}\text { Amills et al. (2003); } \\
\text { Wei et al. (2009) }\end{array}$ \\
\hline 2 & $\begin{array}{l}\text { Insulin-like } \quad \text { growth } \\
\text { factor }(\boldsymbol{I G F})\end{array}$ & $\begin{array}{l}\text { Body weight, daily } \\
\text { gain, feed intake. }\end{array}$ & $\begin{array}{l}\text { Black Penedesenca (PN } \\
\text { and MN) }\end{array}$ & Amills et al. (2003) \\
\hline 2 & $\begin{array}{l}\text { Insulin-like } \begin{array}{r}\text { growth } \\
\text { factor }\end{array} \\
\text { proteinding, }(\boldsymbol{I G F B P}) 1 \text { and } 3\end{array}$ & $\begin{array}{l}\text { Body weight, feed } \\
\text { conversion. }\end{array}$ & $\begin{array}{l}\text { Commercial broiler } \\
\text { Jinghai Yellow }\end{array}$ & $\begin{array}{l}\text { Ye et al. }(2006) \\
\text { Ou et al. }(2009) \\
\text { Zhao et al. }(2015)\end{array}$ \\
\hline 2 & $\begin{array}{l}\text { Accessory protein of the } \\
\text { toll like receptor } 4 \text { (MD- } \\
\text { 2) }\end{array}$ & $\begin{array}{l}\text { Body weight, feed } \\
\text { conversion. }\end{array}$ & Commercial broiler & Ye et al. (2006) \\
\hline 3 & $\begin{array}{l}\text { Ornithine decarboxylase } \\
(\boldsymbol{O D C})\end{array}$ & $\begin{array}{l}\text { Body weight, feed } \\
\text { conversion. }\end{array}$ & $\begin{array}{l}\text { Commercial broiler } \\
\text { Korean native chicken } \\
\text { Korean native chicken } \\
\text { (Black: } 90, \quad \text { Grey- } \\
\text { Brown: } 110 \text {,Red- } \\
\text { Brown: } 134, \text { White: } \\
\text { 125, and Yellow- } \\
\text { Brown: } 131 \text { ) }\end{array}$ & $\begin{array}{l}\text { Ye et al. (2006) } \\
\text { Uemoto et al. }(2011) \\
\text { Cahyadi } \text { et al. }(2013)\end{array}$ \\
\hline
\end{tabular}




\begin{tabular}{|c|c|c|c|c|}
\hline 3 & $\begin{array}{l}\text { Gallinacins } 2 \text { to } 5(\text { Gal } 2 \\
\text { to } \mathbf{G a l ~ 5 )}\end{array}$ & $\begin{array}{l}\text { Body weight, daily } \\
\text { gain. }\end{array}$ & $\begin{array}{l}\text { Fayomi and Rhode } \\
\text { Island Red and their } \\
\text { crosses }\end{array}$ & $\begin{array}{l}\text { Saleh et al., (2020a); } \\
\text { Saleh } \text { et } \text { al., (2020b) }\end{array}$ \\
\hline 4 & $\begin{array}{l}\text { Cholecystokinin type A } \\
\text { receptor }(\boldsymbol{C} \boldsymbol{C K} \boldsymbol{A} \boldsymbol{R})\end{array}$ & $\begin{array}{l}\text { Body weight, feed } \\
\text { conversion. }\end{array}$ & $\begin{array}{l}\text { Hinai-dori breed } \\
\text { Tianlu Black N416 }\end{array}$ & $\begin{array}{l}\text { Rikimaru et al. (2012) } \\
\text { Yi et al. (2018) }\end{array}$ \\
\hline 4 & Interleukin-2 (IL-2) & $\begin{array}{l}\text { Body weight, feed } \\
\text { conversion. }\end{array}$ & $\begin{array}{l}\text { Commercial broiler } \\
\text { Mazandaran native }\end{array}$ & $\begin{array}{l}\text { Ye et al. }(2006) \\
\text { Kazemi et al. }(2018)\end{array}$ \\
\hline 4 & $\begin{array}{l}\text { Tumor necrosis } \\
\text { factor-related apoptosis- } \\
\text { inducing ligand } \\
(\text { TRAIL) }\end{array}$ & $\begin{array}{l}\text { Body weight, feed } \\
\text { conversion. }\end{array}$ & Commercial broiler & Ye et al. (2006) \\
\hline 4 & $\begin{array}{l}\text { Bone morphogenetic } \\
\text { protein receptor } 1 \mathrm{~B} \\
(\mathbf{B M P R - 1 B )}\end{array}$ & Body weight. & $\begin{array}{l}\text { Mazandaran native } \\
\text { Fayoumi, } \\
\text { Rhode Island Red }\end{array}$ & $\begin{array}{l}\text { Niknafs et al. (2012) } \\
\text { Ashraf and El- } \\
\text { Tarabany (2015) }\end{array}$ \\
\hline 5 & Calpain 3 & $\begin{array}{l}\text { Body weight, daily } \\
\text { gain. }\end{array}$ & $\begin{array}{l}\text { Commercial lines (S01, } \\
\text { S02, S03, S05, and D99) }\end{array}$ & Zhang et al. (2009) \\
\hline 5 & $\begin{array}{l}\text { Transforming growth } \\
\text { factor- } \beta 3(\boldsymbol{T} \boldsymbol{G} \boldsymbol{F}-\boldsymbol{\beta} 3)\end{array}$ & $\begin{array}{l}\text { Body weight, feed } \\
\text { conversion. }\end{array}$ & Commercial broiler & Ye et al. (2006) \\
\hline 5 & Insulin $(I N S)$ & $\begin{array}{l}\text { Body weight, feed } \\
\text { conversion. }\end{array}$ & $\begin{array}{l}\text { Xinghua } \times \text { White } \\
\text { Recessive Rock }\end{array}$ & $\begin{array}{l}\text { Qiu et al. (2006); Lei et } \\
\text { al. (2007) }\end{array}$ \\
\hline 7 & $\begin{array}{l}\text { Insulin-like growth } \\
\text { factor binding protein-2 } \\
(\boldsymbol{I G F B P}-2)\end{array}$ & $\begin{array}{l}\text { Body weight, daily } \\
\text { gain. }\end{array}$ & $\begin{array}{l}\text { White Recessive Rock } \times \\
\text { Xinghua }\end{array}$ & $\begin{array}{l}\text { Lei et al. (2005); Leng } \\
\text { et al. (2009) }\end{array}$ \\
\hline 8 & $\begin{array}{l}\text { Leptin receptor gene } \\
(\boldsymbol{L E P R})\end{array}$ & $\begin{array}{l}\text { Body weight,feed } \\
\text { intake, feed } \\
\text { conversion. }\end{array}$ & $\begin{array}{l}\text { Yellow meat type N202 } \\
\text { and N301 }\end{array}$ & $\begin{array}{l}\text { El Moujahid et al. } \\
\text { (2014) }\end{array}$ \\
\hline 9 & $\begin{array}{lr}\text { Growth } & \text { hormone } \\
\text { secretagogue } & \text { receptor } \\
\text { (GHSR) } & \end{array}$ & $\begin{array}{l}\text { Body weight, daily } \\
\text { gain. }\end{array}$ & $\begin{array}{l}\text { White Recessive Rock } \times \\
\text { Xinghua }\end{array}$ & Fang et al. (2010) \\
\hline 10 & $\begin{array}{l}\text { Insulin-like growth } \\
\text { factor } 1 \text { receptor }\end{array}$ & $\begin{array}{l}\text { Body weight, daily } \\
\text { gain. }\end{array}$ & $\begin{array}{l}\text { XH, Taihe Silkie, Bei- } \\
\text { jing Fatty, Yangshan, } \\
\text { Dwarf, White Leghorn, } \\
\text { and White Recessive } \\
\text { Rock }\end{array}$ & Lei et al. (2008) \\
\hline 15 & $\begin{array}{l}\text { Macrophage migration } \\
\text { inhibitory factor }(\boldsymbol{M I F})\end{array}$ & $\begin{array}{l}\text { Body weight, feed } \\
\text { conversion. }\end{array}$ & Commercial broiler & Ye et al. (2006) \\
\hline 16 & $\begin{array}{l}\text { major histocompatibility } \\
\text { complex MHC Class II }\end{array}$ & Body weight. & $\begin{array}{l}\text { Commercial broiler } \\
\text { Leung hang khao }\end{array}$ & $\begin{array}{l}\text { Ye et al. }(2006) \\
\text { Molee et al. }(2016)\end{array}$ \\
\hline 17 & $\begin{array}{l}\text { Toll-like receptor } 4 \\
(\boldsymbol{T L R} 4)\end{array}$ & $\begin{array}{l}\text { Body weight, feed } \\
\text { conversion. }\end{array}$ & $\begin{array}{l}\text { Korean Native Black, } \\
\text { Rhode Island Red, } \\
\text { Cornish }\end{array}$ & Lim et al. (2013) \\
\hline 19 & $\begin{array}{l}\text { Inducible nitric oxide } \\
\text { synthase (INOS) }\end{array}$ & $\begin{array}{l}\text { Body weight, feed } \\
\text { conversion. }\end{array}$ & $\begin{array}{l}\text { Commercial broiler } \\
\text { Korean Native Black, } \\
\text { Rhode Island Red, } \\
\text { Cornish }\end{array}$ & $\begin{array}{l}\text { Ye et al. (2006); } \\
\text { Lim et al. (2013) }\end{array}$ \\
\hline 19 & Caspase-1 (CASP1) & $\begin{array}{l}\text { Body weight, feed } \\
\text { conversion. }\end{array}$ & $\begin{array}{l}\text { Fayoumi and } 2 \text { MHC- } \\
\text { congenic Leghorn lines } \\
(\mathrm{G}-\mathrm{B} 1 \text { and G-B2) }\end{array}$ & $\begin{array}{l}\text { Liu and Lamont } \\
(2003)\end{array}$ \\
\hline 20 & $\begin{array}{l}\text { Bone morphogenetic } \\
\text { protein-7 }(\boldsymbol{B M P 7})\end{array}$ & $\begin{array}{l}\text { Body weight, feed } \\
\text { conversion. }\end{array}$ & $\begin{array}{l}\text { Commercial broiler } \\
\text { Commercial broiler }\end{array}$ & $\begin{array}{l}\text { Ye et al. }(2006) \\
\text { Ye et al. }(2006)\end{array}$ \\
\hline 21 & $\begin{array}{l}\text { PR domain containing } \\
16 \text { (PRDM16) }\end{array}$ & Body weight. & Korean native chicken & Cahyadi et al. (2013) \\
\hline 26 & $\begin{array}{l}\text { Thyroid-stimulating } \\
\text { hormone beta subunit } \\
(\boldsymbol{T S H}-\boldsymbol{\beta})\end{array}$ & Body weight. & $\begin{array}{l}\text { Xinghua } \times \text { White } \\
\text { Recessive Rock } \\
\text { Korean Native Black, } \\
\text { Rhode Island Red, } \\
\text { Cornish }\end{array}$ & $\begin{array}{l}\text { Lei et al. (2007) } \\
\text { Seo et al. (2013) }\end{array}$ \\
\hline 27 & $\begin{array}{l}\text { Growth hormone(GH) } \\
\text { and }(\mathbf{G H 1})\end{array}$ & $\begin{array}{l}\text { Body weight, daily } \\
\text { gain. }\end{array}$ & $\begin{array}{l}\text { Xinghua } \times \text { White } \\
\text { Recessive Rock }\end{array}$ & Nie et al. (2005) \\
\hline
\end{tabular}




\begin{tabular}{|c|c|c|c|c|}
\hline & & & $\begin{array}{l}\text { PS broiler } \times \text { Thai } \\
\text { synthetic breeds; Kaen } \\
\text { Thong }(\mathrm{KT}), \text { Khai Mook } \\
\text { Esarn (KM), Soi Nin } \\
(\mathrm{SN}) \text {, and Soi Pet (SP) }\end{array}$ & Anh et al. (2015) \\
\hline Z & $\begin{array}{l}\text { Growth hormone } \\
\text { receptor (GHR) }\end{array}$ & $\begin{array}{l}\text { Body weight, daily } \\
\text { gain. }\end{array}$ & $\begin{array}{l}\text { White Recessive Rock } \times \\
\text { Xinghua } \\
\text { chicken }\end{array}$ & Lei et al. (2007) \\
\hline
\end{tabular}

*Chr = chromosome number.

Results of Zhou et al. (2005) found significant associations $(P<0.05)$ between IGF1-SNP and average daily gains in the $\mathrm{F}_{2}$ generation of hybrids (Leghorn $\times$ broiler and Fayoumi $\times$ broiler). Also, the $I G F-1$ gene polymorphism is associated with growth in chickens as reported by others (Seo et al., 2001; Kita et al., 2005; Li et al., 2009). Nie et al. (2005) found that SNP maintained significant associations with almost all growth traits, in $\mathrm{F}_{2}$ cross (White Recessive Rock Xinghua Chinese chicken). Ahmed (2010) found that body weight at 12 wks of age was associated with IFNG SNP in Fayoumi chickens. Gouda and Essawy (2010) analyzed the polymorphism of $I G F-I$ gene among Egyptian chicken breeds and indicated their significant effects on growth traits of chicken. Ashraf and El-Tarabany (2015) found that the A287G SNP of BMPR-1B gene was associated significantly with body weight at $2^{\text {nd }}$ $(P=0.02), 3^{\text {rd }}(P=0.03), 4^{\text {th }}(P=0.01), 5^{\text {th }}(P=0.03), 6^{\text {th }}$ $(P=0.001), 7^{\text {th }}(P=0.008)$ and $8^{\text {th }}(P=0.01)$ week of age. Ouyang et al. (2016) indicated that two SNP of the GNPDA2 gene were significantly associated with body weight and a number of fatness traits in chicken (P <0.05). Lim et al. (2013) found that the SNP of iNOS gene had a significant association with body weight at 270 days of age $(\mathrm{p}<0.05)$ in both Korean Native Black and Rhode Island Red whereas SNP of $T L R 4$ gene showed insignificant association with body weight ( $\mathrm{p}>0.05)$. Zhao et al. (2015) detected the association between IGFBP-2 and body weight in Jinghai Yellow chickens and three reference chicken populations (Arbor Acre, Youxi, and Bian chickens). Molee et al. (2016) identified seven SNPs of Major Histocompatibility Complex class II gene (C125T, A126T, C209G, C242T, A243T, C244T and A254T) and stated that significant associations between all SNPs and body weight. Kazemi et al. (2018) reported significant associations between the $I L-2$ gene polymorphisms at promoter region and body weight at 8 weeks of age in Mazandaran native fowls $(\mathrm{P} \leq 0.05)$. El Moujahid et al. (2014) reported that four SNPs of leptin receptor gene were significantly associated with body weight at 49 and 70 day of age $(P<0.05)$, and feed intake $(P<0.05)$ in the yellow N202 strain, and feed conversion $(P<0.01)$ in the yellow N301 strain. Yi et al. (2018) found that C334A SNP of Cholecystokinin type A receptor $(C C K A R)$ gene was associated with feed intake $(\mathrm{P}<0.01)$ and significantly associated with the daily gain $(\mathrm{P}<0.05)$ in Chinese local chicken Ianlu Black pure-line N416.
Jin et al. (2018) found that SNP of Pit-1 gene was associated significantly with feed intake $(\mathrm{p}<0.05)$, and body weight at 70 days of age and feed conversion $(\mathrm{p}<0.05)$.

\section{Molecular associations between candidate genes and egg traits:}

Many researchers have studied the associations between candidate genes and egg production and egg quality traits in poultry (Cui et al., 2006; Li et al., 2009; Xu et al., 2011a; 2011b; Zhu and Jiang, 2014; Ngu et al., 2015; Vu and Ngu (2016); Charoensook et al., 2016; Osman et al., 2017; Nguyen et al., 2018; Azmal et al., 2019; Bhattacharya et al., 2019). These molecular associations' studies cited in Table 2 could be outlined as follows:

1) Genes located on chromosome 1: Insulin -like Growth Factor I (IGF-I) (Li et al., 2009; Ngu et al., 2015), Melatonin Receptor $1 \mathrm{~B}(M T N R 1 B)(\mathbf{L i}$ et al., 2013), Matrix metallopeptidase 13 (Yuan et al., 2016),

2) Genes located on chromosome 2: Neuropeptide $Y$ (NPY) (Xu et al., 2011b; Nguyen et al., 2015), Gonadotropin releasing hormone I (GnRHI) (Bhattacharya et al., 2019), Prolactin (PRL) (Cui et al., 2006; Kulibaba 2015; Osman et al., 2017; Nguyen et al., 2018), Vasoactive intestinal peptide receptor- 1 (VIPRI) (Xu et al., 2011b; Nguyen et al., 2018),

3) Genes located on chromosome 3: Vasoactive intestinal peptide (VIP) (Zhou et al., 2010; Nguyen et al., 2018), Follicle-stimulating hormone receptor (FSHR) (Li et al., 2011),

4) Genes located on chromosome 4: Melatonin Receptor 1A and 1C (MTNRIA) and (MTNR1C) (Li et al., 2013), Gonadotropin releasing hormone II (GnRHII) (Bhattacharya et al., 2019),

5) Genes located on chromosome 5: gremlin (GREM1) and (GREM2) (Tyasi et al., 2018),

6) Genes located on chromosome 7: Inhibin $\alpha$ (INHA) (Cui et al., 2019),

7) Genes located on chromosome 9: Ovocalyxin-32 (Fulton et al., 2012),

8) Genes located on chromosome 13: Growth Differentiation Factor 9 Gene (GDF9) (Liu et al., 2018), Dopamine receptor D1 (DRD1) (Tempfli et al., 2015), Rap guanine nucleotide exchange factor 6 (RAPGEF6) (Azmal et al., 2019), 
9) Genes located on chromosome 20: Matrix metalloproteinases (MMP9) (Zhu and Jiang, 2014),

10) Genes located on chromosome 24: Dopamine D2 Receptor (DRD2) (Xu et al., 2011a; 2011b; Ngu et al., 2015),

11) Genes located on chromosome 27: Growth hormone (GH) (Su et al., 2014; Kulibaba, 2015;
Vu and Ngu 2016), Single transducers and activators of transcriptions 5B (STAT5B) (Charoensook et al., 2016)

12)Genes located on chromosome Z: Prolactin receptor gene (PRLR) (Kulibaba, 2015), growth hormone receptor (Kulibaba, 2015).

Table 3. Candidate genes associated with egg production and egg quality traits in poultry as cited in literature

\begin{tabular}{|c|c|c|c|c|c|}
\hline Chr $^{*}$ & Candidate gene & Trait & Breed & Reference & \\
\hline 1 & $\begin{array}{l}\text { Insulin -like Growth } \\
\text { Factor I }(I G F-I)\end{array}$ & Egg production & $\begin{array}{ll}\text { Erlang } & \text { Mountain } \\
\text { Chicken } & \\
\text { Noi Chickens } & \end{array}$ & $\begin{array}{l}\text { Li et al. (2009) } \\
\text { Ngu et al. (2015) }\end{array}$ & \\
\hline 1 & $\begin{array}{l}\text { Melatonin Receptor 1B } \\
(M T N R 1 B)\end{array}$ & Egg production & $\begin{array}{l}\text { Erlang } \\
\text { Chicken }\end{array}$ & Li et al. (2013) & \\
\hline 1 & $\begin{array}{l}\text { Matrix } \\
\text { metallopeptidase } 13\end{array}$ & Egg production & Hy-line Brown & Yuan et al. (2016) & \\
\hline 2 & Neuropeptide Y (NPY) & Egg production & $\begin{array}{l}\text { Ningdu Sanhuang } \\
\text { chickens } \\
\text { Noi Chickens }\end{array}$ & $\begin{array}{l}\text { Xu et al. (2011b) } \\
\text { Ngu et al. (2015) }\end{array}$ & \\
\hline 2 & $\begin{array}{l}\text { Gonadotropin } \\
\text { Releasing Hormone I } \\
(G n R H I)\end{array}$ & $\begin{array}{l}\text { Egg production } \\
\text { Egg quality }\end{array}$ & White Leghorn & $\begin{array}{l}\text { Bhattacharya et } \\
(2019)\end{array}$ & al. \\
\hline 2 & Prolactin $(P R L)$ & Egg production & $\begin{array}{l}\text { Lien Minh chicken, } \\
\text { Poltava clay chicken, } \\
\text { Hubbard F15, Lohman, } \\
\text { Cobb500, } \\
\text { Avian48 } \\
\text { Lien Minh chicken }\end{array}$ & $\begin{array}{l}\text { Cui et al. (2006); } \\
\text { Kulibaba (2015); } \\
\text { Osman et al. (2017) }\end{array}$ & \\
\hline 2 & $\begin{array}{l}\text { Vasoactive Intestinal } \\
\text { Peptide Receptor- } 1 \\
(V I P R 1)\end{array}$ & Egg production & $\begin{array}{l}\text { Ningdu Sanhuang } \\
\text { chickens } \\
\text { Lien Minh chicken }\end{array}$ & $\begin{array}{l}\text { Xu et al. (2011b) } \\
\text { Nguyen et al. (2018) }\end{array}$ & \\
\hline 3 & $\begin{array}{l}\text { Vasoactive Intestinal } \\
\text { Peptide }(V I P)\end{array}$ & Egg production & $\begin{array}{l}\text { Ningdu Sanhuang } \\
\text { chickens } \\
\text { Lien Minh chicken }\end{array}$ & $\begin{array}{l}\text { Zhou et al. 2010) } \\
\text { Nguyen et al. (2018) }\end{array}$ & \\
\hline 3 & $\begin{array}{lr}\text { Follicle } & \text { Stimulating } \\
\text { Hormone } & \text { Receptor } \\
(F S H R) & \end{array}$ & Egg production & $\begin{array}{lr}\text { (Zang, Jining } & \text { Bairi, } \\
\text { Wenchang, } & \text { Luqin, } \\
\text { Xinyang } & \text { Brown, } \\
\text { Lohmann } & \text { Brown } \\
\text { chickens) } & \end{array}$ & Li et al. (2011) & \\
\hline 4 & $\begin{array}{l}\text { Melatonin Receptor 1A } \\
\text { and } 1 \mathrm{C}(M T N R I A) \text { and } \\
(M T N R I C)\end{array}$ & Egg production & $\begin{array}{ll}\text { Erlang } & \text { Mountain } \\
\text { Chicken } & \end{array}$ & Li et al. (2013) & \\
\hline 4 & $\begin{array}{l}\text { Gonadotropin } \\
\text { Releasing Hormone II } \\
(\text { GnRHII) }\end{array}$ & $\begin{array}{l}\text { Egg production } \\
\text { Egg quality }\end{array}$ & White Leghorn & $\begin{array}{l}\text { Bhattacharya et } \\
(2019)\end{array}$ & al. \\
\hline 5 & $\begin{array}{l}\text { Gremlin (GREM1) and } \\
(\text { GREM2) }\end{array}$ & Egg production & Chinese Dagu chickens & Tyasi et al. (2018) & \\
\hline 7 & Inhibin $\alpha$ (INHA) & Egg production & Lu Hua chicken & Cui et al. (2019) & \\
\hline 9 & Ovocalyxin-32 & $\begin{array}{l}\text { Egg production } \\
\text { Egg quality }\end{array}$ & $\begin{array}{l}\text { White Leghorn, } \\
\text { White Plymouth Rock, } \\
\text { Rhode Island Red }\end{array}$ & Fulton et al. (2012) & \\
\hline 13 & $\begin{array}{l}\text { Growth Differentiation } \\
\text { Factor } 9 \text { Gene (GDF9) }\end{array}$ & Egg production & Lu Hua chicken & Liu et al. (2018) & \\
\hline 13 & $\begin{array}{l}\text { Dopamine receptor D1 } \\
(D R D 1)\end{array}$ & Egg production & Hungarian Yellow & Tempfli et al. (2015) & \\
\hline
\end{tabular}




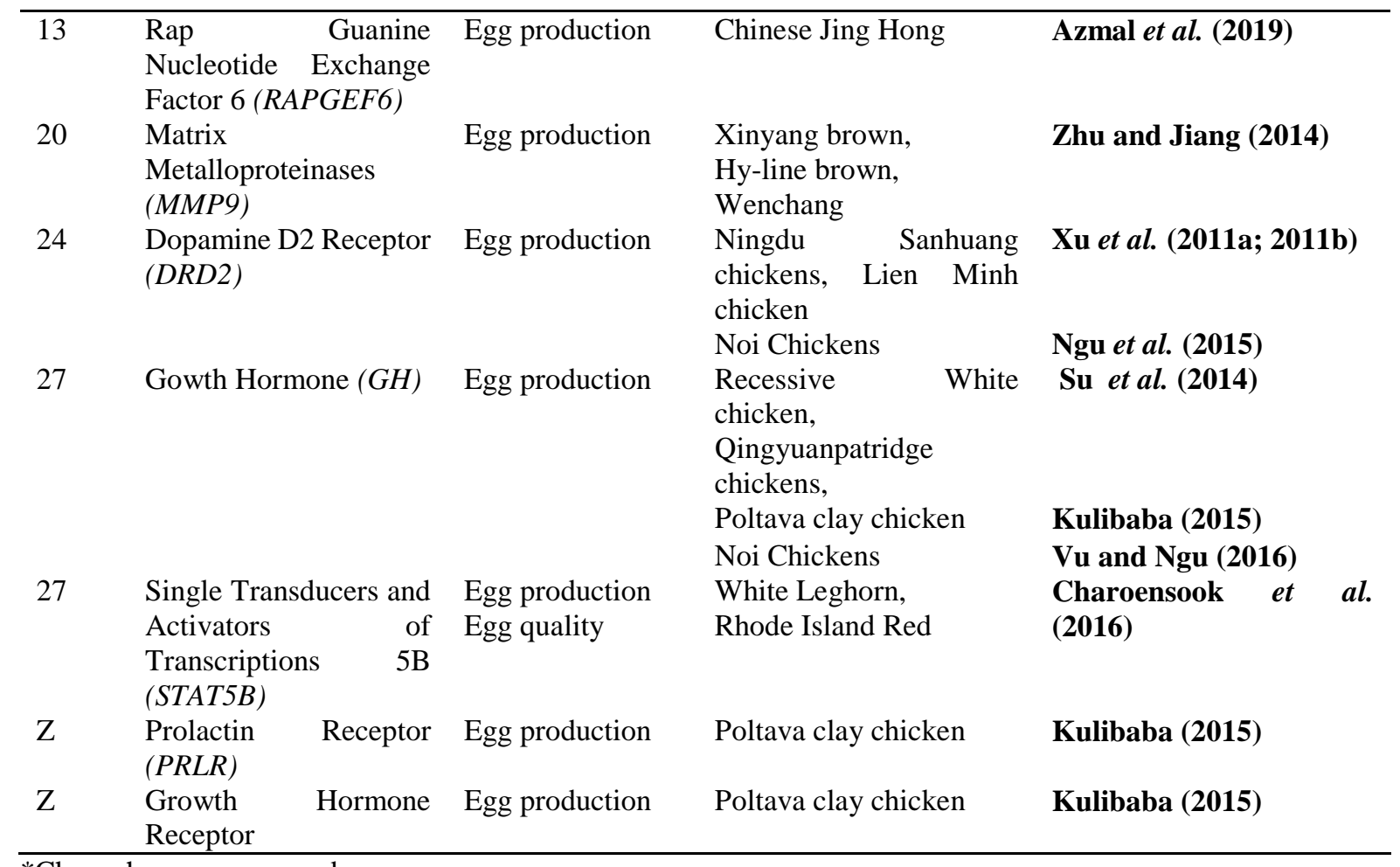

$*$ Chr $=$ chromosome number.

Molecular associations between candidate genes and immune traits:

In the last two decades, several studies have reported the associations of immune genes with immune response, bacterial burden and antibody titers against Salmonella in chickens (Zhou et al., 2001; Lamont et al., 2002; Kramer et al., 2003; Liu and Lamont, 2003; Malek and Lamont, 2003; Zhou and Lamont, 2003a; Malek et al., 2004; Ahmed, 2010; Cahyadi et al., 2013; Khatab et al., 2017; Saleh, 2019). The research conducted on candidate genes associated with immunity traits could be summarized in Table 4. The concept of these molecular associations in terms of chromosome number could be illustrated as follows:

1) Genes located on chromosome 1: Dual-specificity tyrosine-(Y)-phosphorylation regulated kinase 1A (DYRK1A) (Ghebremicael et al., 2008), and Inhibitor of Apoptosis Protein-1 (IAPl) (Kaiser and Lamont, 2002; Tohidi et al., 2013), Cluster of Differentiation 28 (CD28) (Malek et al., 2004), Interferon- $\gamma(I F N-\gamma)$ (Sadeyen et al., 2006; Kazemi et al., 2018),

2) Genes located on chromosome 2: Myeloid differentiation primary response gene 88 (MYD88) (Liu et al., 2015), Accessory protein of the toll like receptor 4 (MD-2),

3) Genes located on chromosome 3: Transforming growth factor $\beta 2$ (TGF- $\beta 2)$ and $\beta 4$ (TGF- $\beta 4)$ (Kramer et al., 2003; Tohidi et al., 2013; Muhsinin et al., 2017), Gallinacins 1 to 13 (Gal 1 to Gal 13) (Hasenstein et al., 2006 and Hasenstein and Lamont, 2007, Saleh et al., 2020c),
4) Genes located on chromosome 4: TNF-related apoptosis-inducing; ligand (TRAIL); Interleukin 2 (IL2) and 8 (IL8) (Kramer et al., 2003; Kazemi et al., 2018),

5) Genes located on chromosome 5: Tumor necrosisfactor-related apoptosis-inducing ligand (TRAIL) (Mariani et al., 2001; Tohidi et al., 2013), Transforming growth factor $\beta 3$ (TGF $\beta 3$ ) (Kramer et al., 2003; Tohidi et al., 2013; Psifidi et al., 2016),

6) Genes located on chromosome 6: Prosaposin (PSAP) (Kramer et al., 2003),

7) Genes located on chromosome 7: Natural resistance-associated, protein 1 (NRAMP1) (Kramer et al., 2003; Tohidi et al., 2013; Psifidi et al., 2016),

8) Genes located on chromosome 14: Lipopolysaccharide- induced tumor necrosis factor $(T N F) \propto$ factor (LITAF) (Malek et al., 2004; Tohidi et al., 2013),

9) Genes located on chromosome 15: Macrophage migration inhibitory factor (MIF) (Malek et al., 2004), immunoglobulin lambda-like polypeptide 1 (IgL)(Kramer et al., 2003), (10) Genes located on chromosome 16: Major histocompatibility complex MHC Class I and II, Major histocompatibility complex MHC class I $\alpha 1, \alpha 2$ and $\beta 1$ domain (Zhou and Lamont, 2003b),

10) Genes located on chromosome 17: Toll like receptor 4 (TLR4) (Hu et al., 1997; Malek et al., 2004; Khatab et al., 2017),

11) Genes located on chromosome 19: Caspase 1 (CASP1) (Kramer et al., 2003), Inducible nitr c oxide synthase (iNOS) (Kramer et al., 2003), 
12) Genes located on chromosome 24: Interleukin 18 (IL-18) (Sadeyen et al., 2006; Kazemi et al., 2018),

13) Genes located on chromosome 26: Polymeric immunoglobulin receptor $(P I G R)$, Map kinase- activated protein kinase 2 (MAPKAPK2),

Interleukin 10 (IL10) and Ligatin (LGTN)

(Ghebremicael et al., 2008).

Table 4. Genes associated with immunity traits in chickens as cited in literature

\begin{tabular}{|c|c|c|c|c|}
\hline Chr $^{*}$ & Candidate gene & Trait & Breed or line & Reference \\
\hline 1 & $\begin{array}{l}\text { Dual Specificity tyrosine- } \\
\text { (Y) Phosphorylation } \\
\text { Regulated Kinase1A } \\
(\text { DYRK1A })\end{array}$ & Bacterial load & Leghorn Fayoumi & $\begin{array}{l}\text { Ghebremicael et al. } \\
(\mathbf{2 0 0 8 )}\end{array}$ \\
\hline 1 & $\begin{array}{l}\text { Cluster of Differentiation } \\
28(\boldsymbol{C D} 28)\end{array}$ & $\begin{array}{l}\text { Bacterial load, antibody } \\
\text { response to Salmonella } \\
\text { enteritidis vaccine }\end{array}$ & $\begin{array}{l}\text { Fayoumi and } 2 \\
\text { MHC-congenic } \\
\text { Leghorn lines (G- } \\
\text { B1 and G-B2) }\end{array}$ & Malek et al. (2004) \\
\hline \multirow[t]{3}{*}{1} & $\begin{array}{l}\text { Inhibitor of Apoptosis } \\
\text { Protein-1 (IAP1) }\end{array}$ & Bacterial load & $\begin{array}{l}\text { Fayoumi and } 2 \\
\text { MHC-congenic } \\
\text { Leghorn lines } \\
\text { (G-B1 and G-B2) }\end{array}$ & $\begin{array}{l}\text { Kaiser and Lamont } \\
(2002)\end{array}$ \\
\hline & & & $\begin{array}{l}\text { Fayoumi and } 2 \\
\text { MHC-congenic } \\
\text { Leghorn lines } \\
(\mathrm{G}-\mathrm{B} 1 \text { and G-B2) }\end{array}$ & $\underset{(2003)}{\text { Liu and Lamont }}$ \\
\hline & & & $\begin{array}{l}\text { Village, } \\
\text { Red Junglefowl }\end{array}$ & Tohidi et al. (2013) \\
\hline \multirow[t]{2}{*}{1} & Interferon- $\gamma(\boldsymbol{I F} \boldsymbol{N}-\boldsymbol{\gamma})$ & Bacterial load & $\begin{array}{l}\text { Inbred lines } 61 \\
\text { and } 15 \mathrm{I}\end{array}$ & Sadeyen et al. (2006) \\
\hline & & & $\begin{array}{l}\text { Mazandaran } \\
\text { native }\end{array}$ & Kazemi et al. (2018) \\
\hline 2 & $\begin{array}{l}\text { Myeloid Differentiation } \\
\text { Primary Response } 88 \\
\text { (MYD88) }\end{array}$ & Bacterial load & Laying hen & Liu et al. (2015) \\
\hline 2 & $\begin{array}{l}\text { Accessory protein of the } \\
\text { toll like receptor } 4(M D-2)\end{array}$ & Bacterial load & $\begin{array}{l}\text { Fayoumi and } 2 \\
\text { MHC-congenic } \\
\text { Leghorn lines } \\
\text { (G-B1 and G-B2) }\end{array}$ & Malek et al. (2004) \\
\hline 3 & $\begin{array}{l}\text { Transforming growth factor } \\
\beta 4(\boldsymbol{T G F}-\boldsymbol{\beta} 4)\end{array}$ & Bacterial load & $\begin{array}{l}\text { Old Dutch breeds, } \\
\text { Broilers } \\
\text { Village, } \\
\text { Red Junglefowl } \\
\text { Sentul chickens }\end{array}$ & $\begin{array}{l}\text { Kramer et al. (2003) } \\
\text { Tohidi et al. (2013) } \\
\text { Psifidi et al. (2016) }\end{array}$ \\
\hline \multirow[t]{2}{*}{3} & $\begin{array}{l}\text { Transforming growth factor } \\
\beta 2(\boldsymbol{T G F}-\boldsymbol{\beta} 2)\end{array}$ & $\begin{array}{l}\text { Bacterial load, } \\
\text { antibody response to }\end{array}$ & $\begin{array}{ll}\text { Old } & \text { Dutch } \\
\text { Broilers } & \end{array}$ & Kramer et al. (2003) \\
\hline & & $\begin{array}{l}\text { Salmonella enteritidis } \\
\text { vaccine }\end{array}$ & Sentul chicken & $\begin{array}{l}\text { Muhsinin et } a l . \\
(2017)\end{array}$ \\
\hline \multirow[t]{2}{*}{3} & $\begin{array}{l}\text { Gallinacins } 1 \text { to } 13 \text { (Gal } 1 \text { to } \\
\text { Gal 13) }\end{array}$ & $\begin{array}{l}\text { Bacterial load, antibody } \\
\text { response to Salmonella } \\
\text { enteritidis vaccine }\end{array}$ & Broiler $\times$ Fayoumi & $\begin{array}{l}\text { Hasenstein et al. } \\
(2006) ; \quad \text { Hasenstein } \\
\text { and Lamont (2007) }\end{array}$ \\
\hline & & & $\begin{array}{l}\text { Fayomi and } \\
\text { Rhode Island Red } \\
\text { and their crosses }\end{array}$ & Saleh et al., (2020c) \\
\hline \multirow[t]{2}{*}{4} & $\begin{array}{l}\text { TNF-related apoptosis- } \\
\text { inducing ligand (TRAIL) }\end{array}$ & Bacterial load & $\begin{array}{l}\text { Fayoumi and two } \\
\text { MHC-congenic } \\
\text { Leghorn lines (G- } \\
\text { B1 and G-B2) }\end{array}$ & $\begin{array}{l}\text { Malek and Lamont } \\
(2003)\end{array}$ \\
\hline & & & $\begin{array}{l}\text { Village, } \\
\text { Red Jungle fowl }\end{array}$ & Tohidi et al. (2013) \\
\hline
\end{tabular}




\begin{tabular}{|c|c|c|c|c|}
\hline 4 & Interleukin 2 (IL2) & Bacterial load & $\begin{array}{l}\text { Old Dutch breeds, } \\
\text { Broilers }\end{array}$ & Kramer et al. (2003) \\
\hline \multirow[t]{2}{*}{4} & Interleukin 8 (ILS) & Bacterial load & $\begin{array}{l}\text { Old Dutch breeds, } \\
\text { Broilers }\end{array}$ & Kramer et al. (2003) \\
\hline & & & $\begin{array}{l}\text { Mazandaran } \\
\text { native }\end{array}$ & Kazemi et al. (2018) \\
\hline 5 & $\begin{array}{l}\text { Tumor necrosis } \\
\text { factor-related apoptosis- } \\
\text { inducing ligand (TRAIL) }\end{array}$ & $\begin{array}{l}\text { Bacterial } \\
\text { (Salmonella } \\
\text { typhimurium) }\end{array}$ & $\begin{array}{l}\text { Village, } \\
\text { Red Jungle fowl }\end{array}$ & Tohidi et al. (2013) \\
\hline \multirow[t]{2}{*}{5} & $\begin{array}{l}\text { Transforming growth factor } \\
\beta 3 \text { (TGFB3) }\end{array}$ & Bacterial load & $\begin{array}{l}\text { Old Dutch breeds, } \\
\text { Broilers }\end{array}$ & Kramer et al. (2003) \\
\hline & & & $\begin{array}{l}\text { Village } \\
\text { Red Jungle fowl } \\
\text { Sentul chickens }\end{array}$ & $\begin{array}{l}\text { Tohidi et al. (2013) } \\
\text { Psifidi et al. (2016) }\end{array}$ \\
\hline \multirow[t]{2}{*}{6} & Prosaposin $(\boldsymbol{P S A P})$ & Bacterial load & $\begin{array}{l}\text { Old Dutch breeds, } \\
\text { Broilers }\end{array}$ & Kramer et al. (2003) \\
\hline & & & $\begin{array}{l}\text { Fayoumi and } 2 \\
\text { MHC-congenic } \\
\text { Leghorn lines } \\
(\mathrm{G}-\mathrm{B} 1 \text { and G-B2) }\end{array}$ & Lamont et al., 2002 \\
\hline \multirow[t]{2}{*}{7} & $\begin{array}{l}\text { Natural resistance- } \\
\text { associated } \\
\text { protein } 1(\text { NRAMP1) }\end{array}$ & Bacterial load & $\begin{array}{l}\text { Fayoumi and } 2 \\
\text { MHC-congenic } \\
\text { Leghorn lines } \\
(\mathrm{G}-\mathrm{B} 1 \text { and G-B2) }\end{array}$ & Lamont et al., 2002 \\
\hline & & & $\begin{array}{l}\text { Laying hen } \\
\text { Sentul chickens }\end{array}$ & $\begin{array}{l}\text { Liu et al. (2015) } \\
\text { Psifidi et al. (2016) }\end{array}$ \\
\hline \multirow[t]{2}{*}{14} & $\begin{array}{l}\text { Lipopolysaccharide- } \\
\text { induced tumor necrosis } \\
\text { factor (TNF) } \alpha \text { factor } \\
(\boldsymbol{L I T A F})\end{array}$ & $\begin{array}{l}\text { Bacterial load, antibody } \\
\text { response to Salmonella } \\
\text { enteritidis vaccine }\end{array}$ & $\begin{array}{l}\text { Fayoumi and } 2 \\
\text { MHC-congenic } \\
\text { Leghorn lines } \\
\text { (G-B1 and G-B2) }\end{array}$ & Malek et al. (2004) \\
\hline & & & $\begin{array}{l}\text { Village, } \\
\text { Red Jungle fowl }\end{array}$ & Tohidi et al. (2013) \\
\hline 15 & $\begin{array}{l}\text { Macrophage migration } \\
\text { inhibitory factor }(\boldsymbol{M I F})\end{array}$ & $\begin{array}{l}\text { Bacterial load, antibody } \\
\text { response to Salmonella } \\
\text { enteritidis vaccine }\end{array}$ & $\begin{array}{l}\text { Fayoumi and } 2 \\
\text { MHC-congenic } \\
\text { Leghorn lines } \\
(\mathrm{G}-\mathrm{B} 1 \text { and G-B2) }\end{array}$ & Malek et al. (2004) \\
\hline 15 & $\begin{array}{l}\text { Immunoglobulin lambda- } \\
\text { like polypeptide } 1(\mathbf{I g} L)\end{array}$ & $\begin{array}{l}\text { Bacterial load Antibody } \\
\text { response to Salmonella } \\
\text { enteritidis vaccine }\end{array}$ & $\begin{array}{l}\text { Old Dutch breeds, } \\
\text { Broilers }\end{array}$ & Kramer et al. (2003) \\
\hline 16 & $\begin{array}{l}\text { Major Histocompatibility } \\
\text { Complex } \boldsymbol{M H C} \text { class } \boldsymbol{I} \\
\boldsymbol{\alpha 1 , \alpha 2 , \beta 1 ~ d o m a i n ~}\end{array}$ & $\begin{array}{l}\text { Antibody response to } \\
\text { Salmonella enteritidis } \\
\text { vaccine }\end{array}$ & $\begin{array}{l}\text { MHC-congenic } \\
\text { Fayoumi } \times \text { G-B1 } \\
\text { Leghorn }\end{array}$ & $\begin{array}{l}\text { Zhou and Lamont } \\
(2003 b)\end{array}$ \\
\hline 17 & $\begin{array}{l}\text { formin binding protein } 1 \\
\text { (ADLO293) }\end{array}$ & $\begin{array}{l}\text { Antibody response to } \\
\text { Salmonella enteritidis } \\
\text { vaccine }\end{array}$ & $\begin{array}{l}\text { Low antibody line } \\
\times \text { High antibody } \\
\text { line }\left(\mathrm{F}_{1} \text { and } \mathrm{F}_{2}\right)\end{array}$ & Yunis et al. ( 2002) \\
\hline \multirow[t]{2}{*}{17} & Toll like receptor 4 (TLR4) & $\begin{array}{l}\text { Bacterial load and } \\
\text { Antibody response to } \\
\text { Salmonella enteritidis } \\
\text { vaccine }\end{array}$ & $\begin{array}{l}\text { Fayoumi and } 2 \\
\text { MHC-congenic } \\
\text { Leghorn lines } \\
\text { (G-B1 and G-B2) }\end{array}$ & Malek et al. (2004) \\
\hline & & & $\begin{array}{l}\text { Fayoumi, } \\
\text { Hyline }\end{array}$ & Khatab et al. (2017) \\
\hline \multirow[t]{2}{*}{19} & Caspase 1 (CASP1) & Bacterial load & $\begin{array}{l}\text { Old Dutch breeds, } \\
\text { Broilers }\end{array}$ & Kramer et al. (2003) \\
\hline & & & $\begin{array}{l}\text { Village } \\
\text { Red Junglefowl }\end{array}$ & Tohidi et al. (2013) \\
\hline 19 & $\begin{array}{l}\text { Inducible nitric oxide } \\
\text { synthase }(\boldsymbol{i N O S})\end{array}$ & Bacterial load & $\begin{array}{l}\text { Old Dutch breeds, } \\
\text { Broilers }\end{array}$ & Kramer et al. (2003) \\
\hline
\end{tabular}




\begin{tabular}{|c|c|c|c|c|c|}
\hline 24 & Interleukin $18(\mathrm{IL}-18)$ & Bacterial load & $\begin{array}{l}\text { Inbred lines } 6 \\
\text { and 15I } \\
\text { Mazandaran } \\
\text { native }\end{array}$ & 51 & $\begin{array}{l}\text { Sadeyen } \text { et al. (2006) } \\
\text { Kazemi } \text { et al. (2018) }\end{array}$ \\
\hline 26 & $\begin{array}{l}\text { Polymeric immunoglobulin } \\
\text { receptor }(\boldsymbol{P I G R})\end{array}$ & Bacterial load & $\begin{array}{l}\text { Leghorn } \\
\text { Fayoumi }\end{array}$ & $x$ & $\begin{array}{l}\text { Ghebremicael et al. } \\
\text { (2008) }\end{array}$ \\
\hline 26 & $\begin{array}{l}\text { Map kinase activated } \\
\text { protein kinase } 2 \\
(\boldsymbol{M A P K A P K 2})\end{array}$ & Bacterial load & $\begin{array}{l}\text { Leghorn } \\
\text { Fayoumi }\end{array}$ & $x$ & $\begin{array}{l}\text { Ghebremicael et al. } \\
\text { (2008) }\end{array}$ \\
\hline 26 & Interleukin 10 (ILI0) & Bacterial load & $\begin{array}{l}\text { Leghorn } \\
\text { Fayoumi }\end{array}$ & $x$ & $\begin{array}{l}\text { Ghebremicael et al. } \\
(2008)\end{array}$ \\
\hline 26 & Ligatin $(\boldsymbol{L G T N})$ & Bacterial load & $\begin{array}{l}\text { Leghorn } \\
\text { Fayoumi }\end{array}$ & $x$ & $\begin{array}{l}\text { Ghebremicael et al. } \\
(2008)\end{array}$ \\
\hline 16 & $\begin{array}{l}\text { Major histocompatibility } \\
\text { complex MHC Class I }\end{array}$ & $\begin{array}{l}\text { Bacterial load } \\
\text { (Salmonella enteritidis) }\end{array}$ & $\begin{array}{l}\text { Fayoumi and } \\
\text { MHC-congenic } \\
\text { Leghorn lines } \\
(\mathrm{G}-\mathrm{B} 1 \text { and G-B2 } \\
\text { MHC-congenic } \\
\text { Fayoumi } \times \text { G-B } \\
\text { Leghorn }\end{array}$ & & $\begin{array}{l}\text { Zhou and Lamont } \\
(2003 b)\end{array}$ \\
\hline
\end{tabular}

$*$ Chr $=$ chromosome number.

Results of Ghebremicael et al. (2008) showed that: 1) The MAPKAPK2 and ILIO genes were highly associated with Salmonella enteritidis burden in spleen tissue and cecal luminal content $(\mathrm{P}<0.001), 2)$ The associations of PIGR with spleen tissue and cecal content were suggestive $(\mathrm{P}<0.05)$, and 3$)$ SNP in $M A P K A P K 2$ and IL10 were strongly associated with Salmonella burden and may be valuable in generating resistant birds by marker-assisted selection. Malek $\boldsymbol{e t}$ al. (2004) stated that the CD28 broiler sire SNP was associated with both bacterial load in the cecum $(\mathrm{P}<$ $0.003)$ and vaccine antibody response $(\mathrm{P}<0.05)$, while the MD2 SNP was associated $(\mathrm{P}<0.04)$ with the bacterial load in the spleen. In Malaysia, Tohidi $\boldsymbol{e t}$ al. (2013) summarized their results in that: 1) The NRAMP1-SacI polymorphism correlated with Salmonella Enteritidis load in the cecum $(\mathrm{P}=0.002)$ and spleen $(\mathrm{P}=0.01)$ of Village chickens, 2$)$ The polymorphisms in the restriction enzyme of $T G F \beta 3$ BsrI, TGF $44-M b o I I$, and TRAIL-StyI were associated with Salmonella Enteritidis burden in the cecum, spleen, and liver of Village chickens and Red Jungle fowl $(\mathrm{P}<0.05)$, and 3) The NRAMP1, TGF 3, $T G F \beta 4$, and TRAIL genes are potential candidates genes to be used in selection programs for increasing genetic resistance against Salmonella Enteritidis in native Malaysian chickens.

In the last two decades, some studies have been performed to detect the gene structure of Salmonella and its ability to resist against antibiotics (Dehkordi et al., 2015). Susceptibility to Salmonella Pullorum infection suggesting that MyD88 gene may be one of the major Salmonella Pullorum resistant genes in innate immune system (Liu et al., 2015). The use of SNP of innate immune genes, such as natural resistance associated macrophage protein 1 Nramp1 (Beaumont et al., 2003), CD28 and MD2 (Malek et al., 2004) and TLR4 (Li et al., 2010) lead to enhancement of Salmonella Pullorum resistance in chicken. The expression of TLR4 and immune related genes, such as Gal 1, Gal 2, IL-8,IL-18, and $I F N-\gamma$, established different degrees of correlation against salmonella in hens (Sadeyen et al., 2006). Ahmed (2010) demonstrated that the novel IFNG promoter SNP was associated with antibody kinetics for Brucella abortus (BA) and Sheep Red Blood Cells (SRBC) in laying hens, suggesting that this cytokine may play a pivotal role in the relationship between immune function and growth.

\section{SNP genotypes and their associations with growth and feeding performance:}

Harini et al. (2013) reported that the TC genotype had heavier body weight than chickswith genotype TT at all ages. Nevertheless, Anh et al. (2015) reported that genotypes of AG and GG having similar positive effects on chicken growth. Zhao et al. (2015) reported that chickens of the AA genotype of $I G F B P-2$ gene had significantly heavier body weight at hatch and 12 weeks of age, than those of the $A B$ genotype $(p<0.05)$, while there were no significant differences among different genotypes in body weight at 4,8 and 16 weeks of age ( $>>0.05)$. Seo et al. (2013) found a significant association between TSH- $\beta$ SNP and body weight at day 150 in Cornish chickens where chicks of CC genotype $(302 \pm 6.3 \mathrm{~g})$ were significantly heavier than that of the GG genotype $(294 \pm 4.5 \mathrm{~g})$ $(p<0.05)$. Jin et al. (2018) found that chicks with the TT genotype of SNP of Pit-1 gene had heavier and significant body weight at 70 day than those of the CT and $\mathrm{CC}$ genotypes and feed conversion was just the opposite $(\mathrm{p}<0.05)$, while the AA genotype had heavier and significant body weight at 70 day and lower feed conversion than those of AT and TT genotypes. 
SNP genotypes and their associations with egg production and egg quality traits:

Li et al. (2013) found that two SNPs genotypes of MTNRIA and MTNRIC genes were significantly associated $(\mathrm{P}<0.01)$ with egg number at 300 days of age (EN) and age at first egg (AFE). Kulibaba (2015) stated that chicks with heterozygous genotype AB of GH gene in Poltavskaya Glinistaya chickens were characterized by higher egg productivity than chicks with genotype BB. Vu and Ngu (2016) also found that genotypes of $G H$ gene were associated with egg production in Noi Chickens. Xu et al. (2011a) found that SNP of VIPR-1 gene associated significantly $(\mathrm{P}<0.05)$ with AFE. Xu et al. (2011b) reported that SNPs genotypes of VIPR-1 were associated significantly $(\mathrm{P}<0.001)$ with EN300 and total egg production and chicks of genotype $\mathrm{CC}$ had lower total egg production after 300 days compared to TT genotype in Ningdu Sanhuang laying chickens. Ngu et al. (2015) reported significant associations between genotypes and egg numbers $(\mathrm{P}<0.05)$ at $28-47$ weeks of age in Noi chicken for IPR-1/TaqI and for VIPR1/HhaI) of Vietnam. Tempfli et al. (2015) found that the genotypes of $P R L$ gene were associated significantly with egg production $(P<0.05)$, whereas genotypes of $D R D 1$ gene associated significantly with egg production at 45 weeks of age $(P<0.05)$. Charoensook et al. (2016) showed that the genotypes of $S T A T 5 B$ gene were significantly associated with egg weight, egg height, shell weight, shell thickness, albumen weight and yolk color $(\mathrm{p}<0.001)$ and chicks of genotype GG had better egg quality traits than AA and $A G$ genotypes. Liu et al. (2018) found that SNP of growth differentiation factor 9 gene was significantly associated with AFE (0.04) and WFE (0.03) and the CC genotype exhibited higher AFE and WFE values than those of TT genotype. Azmal $\boldsymbol{e t}$ al. (2019) showed that genotypes of RAPGEF6 gene were significantly associated $(p<0.0001)$ with egglaying rate at 60 days in Chinese local Jing Hong layer chickens.

SNP genotypes and their associations with disease resistance responses:

Muhsinin et al. (2016) reported that the CC genotype was significantly lower in salmonella pullorum count than TC and TT genotypes of NMAMP1 gene in Sentul chickens $(\mathrm{p}<0.05)$. Khatab et al. (2017) reported that Fayoumi breed is a pure Egyptian conserved breed with one genotype (BB) for TLR4-exon 2 in resistant and susceptible birds compared with Hy-line strain chickens, which have different genotypes (AB and $\mathrm{BB}$ ), where $\mathrm{BB}$ genotype frequency was higher in susceptible birds. So, EcoRITLR4-exon 2 could not use as a marker for susceptibility or resistance to salmonella infection in Fayoumi breed, i.e. it may be used in Hy-line strain for detection the sensitive birds through BB genotype and Taq1-TLR4-exon 1 can be used as a marker for selection resistant birds to salmonella infection in Hy- line strain through AB genotype. Saleh (2019) found that the SNP genotypes of GAL 3, GAL 4 and GAL 5 genes were significantly associated with the caecal Salmonella typhimurium count and the antibodies produced $(\mathrm{p}<0.05)$ in Fayoumi $(\mathrm{F})$, Rhode Island Red (R), $1 / 2 \mathrm{R}^{1 / 2} \mathrm{~F}$ and $1 / 2 \mathrm{~F}^{1} / 2 \mathrm{R}$ genetic groups.

Model for detecting the molecular associations between SNP genotypes of candidate gene and economic traits:

To detect the molecular associations between the genotypes of candidate gene and economic traits, the effects of SNP genotype on different traits must be estimated using the PEST software (Groeneveld, 2006) and applying the following multi-trait animal model (defined in matrix notation):

$\mathbf{y}=\mathbf{X b}+\mathbf{Z}_{\mathbf{a}} \mathbf{u}_{\mathbf{a}}+\mathbf{e}$

Where $\mathbf{y}=$ vector of observed trait on the bird; $\mathbf{b}=$ vector of fixed effects, like sex, genetic group, genotype of candidate gene (three genotypes); $\mathbf{X}$ and $\mathbf{Z}_{\mathbf{a}}=$ incidence matrices corresponding to the fixed and additive random effects of the bird $\left(\mathbf{u}_{\mathbf{a}}\right)$, respectively; $\mathbf{e}=$ vector of random residual effects.

Genome-wide association studies (GWAS) with economic traits in chickens:

Recently, with advances in technologies of next generation sequencing, genome-wide association studies (GWAS) have been used successfully to identify single nucleotide polymorphisms (SNPs) and candidate genes associated with quantitative traits. GWAS have revealed important regions associated with production, reproduction and disease resistance traits in chickens ( Yuan et al., 2015; Fan et al., 2017). One of the essential elements in GWAS is a powerful statistical method that can be employed to identify genetic associations. Methods that using model of population structure by estimating the covariance due to genetic correlation between individuals have been reported to perform better in terms of detecting true associations than models that ignore genomic relationship matrix (Gianola et al., 2016).

In the last decade, a remarkable range of discoveries from genome-wide association studies (GWASs) have been detected in chickens (Moser $\boldsymbol{e t}$ al., 2009; Xu et al., 2013; Sun et al., 2015; Yuan et al., 2015; Gianola et al., 2016; Psifidi et al., 2016; Fan et al., 2017; Pértille et al., 2017; Azmal et al., 2019; Kudinov et al., 2019; Liu et al., 2019; Qu et al., 2019). GWAS results have been shown to be useful for selection of phenotypic traits by a customized gene chip. Xu et al. (2013) reported that chromosome 1 and 4 are the two critical chromosomes influencing growth traits particularly body weight in chickens. Pértille $\boldsymbol{e t}$ al. (2017) observed that twenty significant SNPs ( $\mathrm{P}<7.86 \mathrm{E}-07)$ were associated with feed conversion at 35 days and one significant SNP associated with body weight at 35 days of age, while 
92 suggestive $(\mathrm{P}<1.57 \mathrm{E}-05)$ SNPs were associated with feed conversion, feed intake, feed efficiency, birth weight, and body weight at 35 and 41 days of age. Yi et al. (2015) and Qu et al. (2019) identified candidate genes on GGA4 that provide strong confirmation of their previous reported region for egg weight (Yi et al., 2015) and egg shell traits (Sun et al., 2015). GWAS results of Azmal et al. (2019) showed that five identified SNPs in chromosome 13 were associated with egg production traits of 120 laying birds, which are all located in RAPGEF6 gene. Liu $\boldsymbol{e t}$ al. (2019) found that seven univariate GWAS for age at first egg and egg numbers were performed independently, from which a total of 161 candidate SNPs located on GGA1, GGA2, GGA5, GGA6, GGA9 and GGA24 were identified, thirteen SNP located on GGA6 that may associated with AFE and $P R L H R$ gene that may affect AFE through regulating oxytocin secretion in chickens and sixteen genomewide significant SNPs associated with EN3. Liu et al. (2019) found that genes POLA1, PDK3, PRDX4 and
APOO identified by annotating sixteen genome-wide significant SNPs that can be considered as candidates associated with EN3 and did not find any candidate gene for the total egg number. Kudinov et al. (2019) observed significant associations for yield of extraembryonic fluid, age at first egg, body weight and egg weight in genotyping of 146 birds in GWASs and reported that on chromosome 2, there was an association with immune resistance in the white day old chick down colour (DOCDC).

Suggested genetic improvement program in the Egyptian chickens using molecular approaches:

Using traditional selection for genetic improvement in poultry will cause slow and low genetic progress and using biotechnology techniques are the best way to achieve fast genetic improvement. The necessary steps to perform a genetic improvement program in the Egyptian breeds of chickens using the molecular applications could be summarized as follows:

\footnotetext{
Step Procedure and Executable Approach

No

1. Recording the phenotypic data from full pedigree file for all birds (hens and cocks) to evaluate the birds genetically:

Adequate number of birds will be used. Not adequate records must be discarded to ensure a homogenous data set.

Pedigreed birds will be used to estimate the breeding value for the economic traits in local breeds of chickens. The breeding value (EBV) will be estimated by an animal model using BLUPF90 software (Misztal et al., 2018) fitting univariate approach. The assumed model will be:
}

$$
\mathbf{y}=\mathbf{X b}+\mathbf{Z a}+\mathbf{e}
$$

where, $y=$ vector of observations, $b=$ vector of fixed effects with an incidence matrix $X, a=$ vector of random bird effects with incidence matrix $\mathrm{Z}$, and $\mathrm{e}=$ vector of random residual effects

2. Determine the list of main equipments required and the main list of chemicals for DNA extraction:

The necessary equipments chemicals are: PCR machine, Real-time PCR, Gel electrophoresis, Gel Documentation System, Vortex, Centrifuge $30000 \mathrm{rpm}$ under cooling, Biosafety cabinet, EDTA, Ethidium Bromide, Magnesium chloride, dNTPs, PCR Master Mix (2X), Sybr green master mix kits, PFU Taq DNA Polymerase, Agarose, Phenol (nucleic acid grade), DNA isolation Kit from animal tissues, Micropipettes set, Eppendorf.

3. Collecting the blood samples and DNA extraction (Abdel A'al et al., 2016; 2017):

The blood samples will be collected under sterile conditions by jugular vein puncture using 5-ml vacuum tubes of polypropylene containing EDTA. The samples will transfer to the laboratory in iceboxes containing ice packs and stored at $-20^{\circ} \mathrm{C}$ until extract the genomic DNA. Genomic DNA extraction: genomic DNA will extract using a standard phenol-chloroform extraction protocol and ethanol precipitation methods.

4. Reporting candidate genes from QTLs data base:

For bovine genome, a list of previously reported QTL for economic traits was obtained from animal QTL db, release 30 (Hu et al., 2016) (http://www.animalgenome.org/QTLdb).

5. Preparing the genotyping files (Liu et al., 2019) and genotyping the birds:

The birds will be genotyped using SNPs markers.

6. Applying the Genome-Wide Association Study (GWAS):

The birds with more than $20 \%$ missing marker genotype will excluded from the analysis. A SNP will be removed from the analysis if it had minor allele frequency less than 0.02. Filtration of the marker data was performed with Plink software (Purcell et al., 2007). A genome wide association study will performed using linear regression model in the way of regressing the average daily deviations on SNP alleles and will be implemented by Plink software. The PLINK software will be used for analyzing the GWAS using the following model:

$y=x b+e$ 
Where, $\mathrm{y}$ is a vector of each GBVs of the genotyped individuals, $\mathrm{x}$ is each SNP information and $\mathrm{b}$ is coefficient value for $\mathrm{x}$ vector.

7. Applying SNP association test:

The National Center for Biotechnology Information (NCBI) database will be used to detect the genes closely associated with economic traits in poultry.

8. Estimating the genomic breeding values (GBV or GCTA) to be applied in genomic selection: The genomic breeding values (GBV) will be estimated as the sum of the effects of dense genetic markers, or haplotypes of these markers, across the entire genome capturing all the quantitative trait loci (QTL) that contribute to variation in a trait. The QTL effects detected from individual single nucleotide polymorphism (SNP) markers, are first estimated in a large reference population with phenotypic information (Abdel A'al et al., 2016; 2017). In subsequent generations or in related populations, only marker information is required to calculate GBV.

9. $\quad$ Evaluating the prediction accuracy (EBV vs GBV) :

The correlation between the estimated traditional breeding values (EBV; using phenotypic data and pedigree) and the genomic breeding values (GBV) must be estimated. The reliability of GBV and the correlation between EBV and GBV were used to evaluate the prediction accuracy (Moser et al., 2009).

10. Estimating the Genomic Best Linear Unbiased Predictions (GBLUP) and SNP-GBLUP:

The mixed model will be used to estimate the breeding values GBLUP and best linear unbiased estimation. These models estimate the fixed effects such as sex and SNPs and the random effects for a given quantitative phenotype. The proposed mixed model and its solution are presented as follows:

$$
\mathbf{y}=\mathbf{X b}+\mathbf{Z u}+\mathbf{e}
$$

Where $\mathrm{y}$ is the vector of phenotypic values, $\mathrm{X}$ and $\mathrm{Z}$ are the design matrices; $\mathrm{b}$ and $\mathrm{u}$ are vectors of fixed and random effects, respectively. To compare the estimated breeding values (EBV) of the total SNPs with trimmed SNPs, we will use the G-BLUP which adopts the genomic relationship matrix (GRM) with total pruned SNPs and SNP-GBLUP which utilizes the SNP-SNP relationship matrix with trimmed SNPs (Lee et al., 2014).

11. Applying genomic selection program (GS):

The genomic selection (GS) is a form of marker assisted selection in which genetic markers covering the whole genome are used so that all quantitative trait loci (QTL). This approach has become feasible due to revolution in SNP discovery method like gene sequencing and SNP genotyping on DNA chip. The genomic breeding values (GBV) and their reliabilities for the genotyped birds will be used to select the best cocks and hens based on their GBV to be parents for the next generation (genomic selection).

\section{References Cited}

Abdel A'al, M.H., Khalil, M.H., Iraqi, M.M. and El-Moghazy, G.M., 2016. Quantitative trait loci affecting growth performance in F2 intercross between Golden Montazah and White Leghorn chickens. In 3rd International Conference on Biotechnology Applications in Agriculture (ICBAA), Benha University, Sharm El-Sheikh, 59 April 2016, Egypt.

Abdel A'al, M.A., Iraqi, M.M., Khalil, M.H., ElMoghazy, G.M. and El-Atrouny, M.M. 2017. Quantitative Trait Loci Associated with Egg Traits in F2 Intercross between Golden Montazah and White Leghorn Chickens. Benha Journal of Applied Sciences. 2 (3):1-10.

Ahmed, A. 2010. Associations of polymorphisms in four immune-related genes with antibody kinetics and body weight in chickens. Asian-Australasian Journal of Animal Sciences, 23, 1089-1095.

Amills, M., Jimenez, N., Villalba, D., Tor, M., Molina, E., Cubilo, D., Marcos, C., Francesch, A., Sanchez, A. and Estany, J. 2003. Identification of three single nucleotide polymorphisms in the chicken insulin-like growth factor 1 and 2 genes and their associations with growth and feeding traits. Poultry Science, 82, 1485-1493.

Anh, N. T. L., Kunhareang, S. and Duangjinda, M. 2015. Association of chicken growth hormones and insulin-like growth factor gene polymorphisms with growth performance and carcass traits in Thai broilers. Asian-Australasian Journal of Animal Sciences, 28, 1686-1695.

Ashraf, A. and El-Tarabany, M. S. 2015. Association of single nucleotide polymorphism in bone morphogenetic protein receptor 1B (BMPR1B) Gene with growth traits in chicken. Kafkas. Univ. Vet. Fak. Derg. 21, 819-824.

Azmal, S. A., Bhuiyan, A. A., Omar, A. I., Ma, S., Sun, C., Han, Z., Zhang, M., Zhao, S. and Li, S. 2019. Novel polymorphisms in RAPGEF6 gene associated with egg-laying rate in Chinese Jing Hong chicken using Genome-Wide SNP Scan. Genes, 10, 384-404.

Beaumont, C., Protais, J., Pitel, F., Leveque, G., Malo, D., Lantier, F., Plisson-Petit, F., Colin, P., Protais, M. and Le Roy, P. 2003. Effect of two candidate genes on the Salmonella carrier state in fowl. Poultry Science, 82, 721-726. 
Bhattacharya, T.K., Chatterjee, R.N., Dange, M. and Bhanja, S.K., 2019. Polymorphisms in GnRHI and GnRHII genes and their association with egg production and egg quality traits in chicken. British Poultry Science, 60(3),187-194.

Bloom, S.E., Delaney, M.E. and Muscarella, D.E. 1993. Constant and variable features of avian chromosomes. In: Etches RJ, Gibbins AMV, Editors. Manipulation of the avian genome. Boca Raton, FL: CRC Press 39-60.

Brown, S. M. 1999. Snapping Up SNPs. BioTechniques, 26, 1090-1093.

Bulut, Z., Kurar, E., Ozsensoy, Y., Nizamlioglu, M., Garip, M., Yilmaz, A., Caglayan, T., Dere, S., Kurtoglu, V. andDogan, M. 2013. Determination of chromosomal regions affecting body weight and egg production in Denizli X White Leghorn F2 populations. Eurasian Journal of Veterinary Sciences, 29, 30-38.

Cahyadi, M., Seo, D., Jin, S., Choi, N., Park, H.-B., Heo, K. N., Kang, B. S., Jo, C. and Lee, J. H. 2013. Association of SNPs in ODC and PRDM16 with body weight traits in Korean Native Chicken. Korean Journal of Poultry Science, 40, 157-162.

Cao, Z., Wang, S., Wang, Q., Wang, Y. and Li, H. 2007. Association of spot $14 \alpha$ gene polymorphisms with body weight in the chicken. Poultry Science, 86, 1873-1880.

Charoensook, R., Wichasit, N., Pechrkong, T., Incharoen, T. and Numthuam, S. 2016. STAT5B gene polymorphisms are associated with egg production and egg quality traits in laying hens. Asian Journal of Animal and Veterinary Advances, 11 (12): 847-853. DOI: 10.3923/ajava.2016.847.

Cui, J.X., Du, H.L., Liang, Y., Deng, X.M., Li, N. and Zhang, X.Q. 2006. Association of polymorphisms in the promoter region of chicken prolactin with egg production. Poultry Science, 85: 26-31.

Cui, Z., Liu, L., Zhao, X., Ran, J., Wang, Y., Yin, H., Li, D. and Zhu, Q. 2019. Analysis of expression and single nucleotide polymorphisms of INHA gene associated with reproductive traits in chickens. BioMed Research International, 2019, 11 pages. https://doi.org/10.1155/2019/8572837.

Dehkordi, M. S., Doosti, A. and Arshi, A. 2015. Deletion of Salmonella enterica serovar typhimurium sipC gene. Asian Pacific Journal of Tropical Biomedicine, 5, 987-991.

El Moujahid, E. M., Chen, S., Jin, S., Lu, Y., Zhang, D., Ji, C. and Yang, N. 2014. Association of leptin receptor gene polymorphisms with growth and feed efficiency in meat-type chickens. Poultry Science, 93, 1910-1915.

Erhardt, G. and Weimann, C. 2007. Use of molecular markers for evaluation of genetic diversity and in animal production. Arch. Latinoam. Production Animal. 15, 63-66.
FAO. 2011. Molecular genetic characterization of animal genetic resources. FAO Animal Production and Health Guidelines. No. 9. Rome.

Fan, Q., Wu, P., Dai, G., Zhang, G., Zhang, T., Xue, Q., Shi, H. and Wang, J. 2017. Identification of 19 loci for reproductive traits in a local Chinese chicken by genome-wide study. Genetics and Molecular Research, 16 (1): gmr16019431.

Fang, M., Nie, Q., Luo, C., Zhang, D. and Zhang, X. 2010. Associations of GHSR gene polymorphisms with chicken growth and carcass traits. Molecular Biology Reports, 37, 423-428.

Fontanesi, L., Tazzoli, M., Scotti, E. and Russo, V. 2008. Analysis of candidate genes for meat production traits in domestic rabbit breeds. Proceedings of the 9th World Rabbit Congress, Verona, Italy, 10-13 June 2008. World Rabbit Science Association, 79-84.

Fulton, J.E., Soller, M., Lund, A.R., Arango, J. and Lipkin, E., 2012. Variation in the ovocalyxin-32 gene in commercial egg-laying chickens and its relationship with egg production and egg quality traits. Animal Genetics, 43, 102-113.

Ghebremicael, S., Hasenstein, J. and Lamont, S. 2008. Association of interleukin-10 cluster genes and Salmonella response in the chicken. Poultry Science, 87, 22-26.

Gianola, D., Fariello, M. I., Naya, H. and Schön, C.C. 2016. Genome-wide association studies with a genomic relationship matrix: a case study with wheat and arabidopsis. G3: Genes, Genomes, Genetics, 6, 3241-3256.

Goraga, Z., Nassar, M. and Brockmann, G. 2012. Quantitative trait loci segregating in crosses between New Hampshire and White Leghorn chicken lines: I. egg production traits. Animal Genetics, 43, 183-189.

Gouda, E. M. and Essawy, G. S. 2010. Polymorphism of insulin-like growth factor I gene among chicken breeds in Egypt. Zeitschrift für Naturforschung C, 65, 284-288.

Groeneveld, E. 2006. PEST User's Manual. Institute of Animal Husbandry and Animal Behaviour, FAL, Germany.

Harini, N. M., Duryadi, S., Sri, S. and Cece, S. 2013. Polymorphisms of Insuline-like growth factor-I (IGF-1) and pituitary positive transcription factor-1 (Pit-I) genes and their effect on growth traits in indonesian native chickens. Proceeding of the International Conference on 4th Green Technology Faculty of Science and Technology, January 2013, State Islamic University of Malang, Indonesia.

Hu, J., Bumstead, N., Barrow, P., Sebastiani, G., Olien, L., Morgan, K. and Malo, D. 1997. Resistance to salmonellosis in the chicken is linked to NRAMP1 and TNC. Genome Research, 7, 693-704. 
Hu, Z.L., Park, C.A., Reecy, J.M., 2016. Developmental progress and current status of the Animal QTLdb. Nucleic Acids Res. 44, 827-833.

Ikeobi, C., Woolliams, J., Morrice, D., Law, A., Windsor, D., Burt, D. and Hocking, P. 2002. Quantitative trait loci affecting fatness in the chicken. Animal Genetics, 33, 428-435.

Iraqi, M. M., Hanafi, M., El-Moghazy, G. M., ElKotait, A. and A'al, M. A. 2011. Estimation of crossbreeding effects for growth and immunological traits in a crossbreeding experiment involving two local strains of chickens. Livestock Research for Rural Development, 23, Article \#82..

Jacobsson, L., Park, H., Wahlberg, P., Fredriksson, R., Perez-Enciso, M., Siegel, P., and Andersson, L. 2005. Many QTLs with minor additive effects are associated with a large difference in growth between two selection lines in chickens. Genetical Research, 86(2): 115-125.

Jin, S., He, T., Yang, L., Tong, Y., Chen, X. and Geng, Z. 2018. Association of polymorphisms in Pit-1 gene with growth and feed efficiency in meat-type chickens. Asian-Australasian Journal of Animal Sciences, 31, 1685-1690.

Kaiser, M. and Lamont, S. 2002. Microsatellites linked to Salmonella enterica Serovar Enteritidis burden in spleen and cecal content of young F1 broiler-cross chicks. Poultry Science, 81, 657-663.

Kalinowski, S. T., Taper, M. L. and Marshall, T. C. 2007. Revising how the computer program CERVUS accommodates genotyping error increases success in paternity assignment. Molecular Ecology, 16, 1099-1106.

Kazemi, H., Najafi, M., Ghasemian, E., RahimiMianji, G. and Pirsaraei, Z. A. 2018. Polymorphism detection of promoter region of IFN- $\gamma$ and IL-2 genes and their association with productive traits in Mazandaran native breeder fowls. Journal of Genetics, 97, 843-851.

Khalil, M.H., Iraqi, M.M., El-Moghazy, G.M. and Abdel A'al, M.H. 2016. QTL and chromosomal mapping for growth and egg performance in chickens: Applications and emphasis of results in Egypt. In 3rd International Conference on Biotechnology Applications in Agriculture (ICBAA), Benha University, Sharm El-Sheikh, 59 April 2016, Egypt.

Khatab, Shymaa A., Hemeda, S.A., El-Nahas, Abeer F. and Abd El Naby, Walaa S.H. 2017. Polymorphisms of TLR4 gene and its association with genetic resistance to salmonella enteritidis infection in Fayoumi breed and Hy-line strain in Egypt. Alexandria Journal for Veterinary Sciences, 55, 1-9.

Kita, K., Nagao, K. and Okumura, J. 2005. Nutritional and tissue specificity of IGF-I and IGFBP-2 gene expression in growing chickens-a review. Asian-Australasian Journal of Animal Sciences, 18, 747-754.
Kramer, J., Malek, M. and Lamont, S. 2003. Association of twelve candidate gene polymorphisms and response to challenge with Salmonella enteritidis in poultry. Animal Genetics, 34, 339-348.

Kudinov, A. A., Dementieva, N. V., Mitrofanova, O. V., Stanishevskaya, O. I., Fedorova, E. S., Larkina, T. A., Mishina, A. I., Plemyashov, K. V., Griffin, D. K. and Romanov, M. N. 2019. Genome-wide association studies targeting the yield of extraembryonic fluid and production traits in Russian White chickens. BMC Genomics, 20, 270-282.

Kulibaba, R.A. 2015. Polymorphism of growth hormone, growth hormone receptor, prolactin and prolactin receptor genes in connection with egg production in poltava clay chicken. Agricultaral Biology, 50(2):198-207.

Kumar, S., Dilbaghi, N., Ahlawat, S., Bina, M., Tantia, M. and Vijh, R. 2007. Genetic relationship among chicken populations of India based on SNP markers of Myostatin gene (GDF 8). International Journal of Poultry Science 9, 684688.

Lamont, S., Kaiser, M. and Liu, W. 2002. Candidate genes for resistance to Salmonella enteritidis colonization in chickens as detected in a novel genetic cross. Veterinary Immunology and Immunopathology, 87, 423-428.

Lander, E. S. 1996. The new genomics: global views of biology. Science, 274, 536-539.

Lee, W., Tonelli, M. \& Markley, J. L. 2014. NMRFAM-SPARKY: enhanced software for biomolecular NMR spectroscopy. Bioinformatics, 31, 1325-1327.

Lei, M., Nie, Q., Peng, X., Zhang, D. and Zhang, X. 2005. Single nucleotide polymorphisms of the chicken insulin-like factor binding protein 2 gene associated with chicken growth and carcass traits. Poultry Science, 84, 1191-1198.

Lei, M., Luo, C., Peng, X., Fang, M., Nie, Q., Zhang, D., Yang, G. and Zhang, X. 2007. Polymorphism of growth-correlated genes associated with fatness and muscle fiber traits in chickens. Poultry Science, 86, 835-842.

Lei, M., Peng, X., Zhou, M., Luo, C., Nie, Q. and Zhang, X. 2008. Polymorphisms of the IGF1R gene and their genetic effects on chicken early growth and carcass traits. BMC Genetics, 9, 70-79.

Leng, L., Wang, S., Li, Z., Wang, Q. And Li, H. 2009. A polymorphism in the 3 '-flanking region of insulin-like growth factor binding protein 2 gene associated with abdominal fat in chickens. Poultry Science, 88, 938-942.

Li, D.Y., Zhang, L., Smith, D.G., Xu, H.L., Liu, Y.P., Zhao, X.L., Wang, Y. and Zhu, Q., 2013. Genetic effects of melatonin receptor genes on chicken reproductive traits. Czech J. Anim. Sci. 58(2), 58-64 . 
Li, G., Sun, D.X., Yu, Y., Liu, W.J., Tang, S.Q., Zhang, Y., Wang, Y.C., Zhang, S.L., Zhang, Y., 2011. Genetic effect of the follicle-stimulating hormone receptor gene on reproductive traits in Beijing You chickens. Poultry Science. 90, 24872492.https://doi.org/10.3382/ps.2010-01327.

Li, H., Deeb, N., Zhou, H., Mitchell, A., Ashwell, C. and Lamont, S. J. 2003. Chicken quantitative trait loci for growth and body composition associated with transforming growth factor-beta genes. Poultry Science, 82, 347-356.

Li, H.F., Zhu, W.Q., Chen, K.W., Wu, X., Tang, Q.P., Gao, Y.S., Song, W.T., Xu, W.J and Xu, H.L. 2009. Polymorphism in NPY and IGF-I genes associate with reproductive traits in Wenchang chicken. African Journal of Biotechnology 8: 4744-4748.

Li, P., Xia, P., Wen, J., Zheng, M., Chen, J., Zhao, J., Jiang, R., Liu, R. and Zhao, G. 2010. Upregulation of the MyD88-dependent pathway of TLR signaling in spleen and caecum of young chickens infected with Salmonella serovar Pullorum. Veterinary Microbiology, 143, 346-351.

Lim, H., Han, J., Oh, J., Lee, H., Jeon, G., Lee, J., Seo, D., Cahyadi, M., Song, K. and Choi, K. 2013. Association of SNPs from iNOS and TLR-4 genes with economic trait in chicken. Korean Journal of Poultry Science, 40, 83-89.

Liu, Z., Yang, N., Yan, Y., Li, G., Liu, A., Wu, G. and Sun, C. 2019. Genome-wide association analysis of egg production performance in chickens across the whole laying period. BMC Genetics, 20, 67-76.

Liu, L., Cui, Z., Xiao, Q., Zhang, H., Zhao, X., Wang, Y., Yin, H., Li, D. and Zhu, Q. 2018. Polymorphisms in the chicken growth differentiation factor 9 gene associated with reproductive traits. BioMed Research International,2018 online.

Liu, W. and Lamont, S. 2003. Candidate gene approach: Potentional association of Caspase-1, Inhibitor of Apoptosis Protein-1, and Prosaposin gene polymorphisms with response to Salmonella enteritidis challenge or vaccination in young chicks. Animal Biotechnology, 14, 61-76.

Liu, X. Q., Wang, F., Jin, J., Zhou, Y.G., Ran, J.S., Feng, Z.Q., Wang, Y. and Liu, Y.P. 2015. MyD88 polymorphisms and association with susceptibility to salmonella pullorum. BioMed Research International, 6, 1-7.

Liu, X., Zhang, H., Li, H., Li, N., Zhang, Y., Zhang, Q., Wang, S., Wang, Q. and Wang, $H$. 2008. Fine-mapping quantitative trait loci for body weight and abdominal fat traits: effects of marker density and sample size. Poultry Science. 87:1314-1319.

Mackay, T.F., Stone, E.A. and Ayroles, J.F. 2009. The genetics of quantitative traits: challenges and prospects. Nature Reviews Genetics, 10, 565-577.
Malek, M. and Lamont, S. J. 2003. Association of INOS, TRAIL, TGF- $\beta 2$, TGF- $\beta 3$, and IgL genes with response to Salmonella enteritidis in poultry. Genetics Selection Evolution, 35, 99-111.

Malek, M., Hasenstein, J. and Lamont, S. 2004. Analysis of chicken TLR4, CD28, MIF, MD-2, and LITAF genes in a Salmonella enteritidis resource population. Poultry Science, 83, 544-549.

Meng, H., Zhao, J., Li, Z. and Li, H. 2005. Single nucleotide polymorphisms on peroxisome proliferator-activated receptor genes associated with fatness traits in chicken. Asian-Australasian Journal of Animal Sciences, 18, 1221-1225.

Misztal, I., Tsuruta, S. Lourenco, D.A.L. Masuda, Y. Aguilar, I. Legarra, A. and Vitezica, Z. 2018. Manual for BLUPF90 family of programs. Vol. 2018. Accessed Decamber 17, 2018. http://nce.ads.uga.edu/wiki/lib/exe/fetch.php?med ia=blupf90 all7.pdf

Molee, A., Kongroi, K., Kuadsantia, P., Poompramun, C. and Likitdecharote, B. 2016. Association between single nucleotide polymorphisms of the major histocompatibility complex class II gene and Newcastle disease virus titre and body weight in Leung Hang Khao chickens. Asian-Australasian Journal of Animal Sciences, 29, 29-35.

Moser, G., Tier, B., Crump, R. E., Khatkar, M. S. and Raadsma, H. W. 2009. A comparison of five methods to predict genomic breeding values of dairy bulls from genome-wide SNP markers. Genetics Selection Evolution, 41, 56-72.

Muhsinin, M., Ulupi, N., Gunawan, A., Wibawan, I. and Sumantri, C. 2016. Association of NRAMP1 polymorphisms with immune traits in Indonesian native chickens. Int. J Poult. Sci., 15, 401-406.

Muhsinin, M., Ulupi, N., Gunawan, A., Wibawan, I. W. T. and Sumantri, C. 2017. g. 640T> C Polymorphism of the TGF- $\beta 2$ gene is associated with salmonella pullorum resistance in Indonesian chickens. Animal Production, 19, 81-92.

Nassar, M., Goraga, Z. and Brockmann, G. 2013. Quantitative trait loci segregating in crosses between New Hampshire and White Leghorn chicken lines: III. Fat deposition and intramuscular fat content. Animal Genetics, 44, 62-68.

Nassar, M., Goraga, Z. and Brockmann, G. 2015. Quantitative trait loci segregating in crosses between New Hampshire and White Leghorn chicken lines: IV. Growth performance. Animal Genetics, 46, 441-446.

Ngu, N.T., Xuan, N.H., Vu, C.T., An, N.T., Dung, T.N. and Nhan, N.T.H. 2015. Effects of genetic polymorphisms on egg production in indigenous Noi chicken. Journal of Experimental Biology and Agricultural Sciences. 3(6):487-493.

Nguyen, T.T.B., Duc, N.H., Quy, V.C., Yen, H.T., Loan, T.T., Thuy, D.T.N., Tien, V.T. and Thuy, N.T.D. 2018. Effect of nucleotide polymorphism 
of candidate genes on egg production traits in native Lien Minh chicken. Livestock Research for Rural Development. Volume 30, Article \#103. Retrieved February 1, 2020, from http://www.lrrd.org/lrrd30/6/ntdt30103.html

Nie, Q., Sun, B., Zhang, D., Luo, C., Ishag, N., Lei, M., Yang, G. and Zhang, X. 2005. High diversity of the chicken growth hormone gene and effects on growth and carcass traits. Journal of Heredity, 96, 698-703.

Nie, Q., Fang, M., Xie, L., Zhou, M., Liang, Z., Luo, Z., Wang, G., Bi, W., Liang, C. and Zhang, W. 2008. The PIT1 gene polymorphisms were associated with chicken growth traits. $B M C$ Genetics, 9, 20-27.

Niknafs, S., Nejati-Javaremi, A., MehrabaniYeganeh, H. and Fatemi, S. A. 2012. Estimation of genetic parameters for body weight and egg production traits in Mazandaran native chicken. Tropical Animal Health and Production, 44, 14371443.

Nones, K., Ledur, M.C., Ruy, D.C., Baron, E.E., Melo, C.M.R., Moura, A.S.A.M.T., Zanella, E.L., Burt, D.W. and Coutinho, L.L., 2006. Mapping QTLs on chicken chromosome 1 for performance and carcass traits in a broiler $\mathrm{x}$ layer cross. Animal Genetics, 37(2): 95-100.

Ou, J., Tang, S., Sun, D. and Zhang, Y. 2009. Polymorphisms of three neuroendocrinecorrelated genes associated with growth and reproductive traits in the chicken. Poultry Science, $88,722-727$.

Ouyang, H., Zhang, H., Li, W., Liang, S., Jebessa, E., Abdalla, B. A. and Nie, Q. 2016. Identification, expression and variation of the GNPDA2 gene, and its association with body weight and fatness traits in chicken. Peer J, 4, 2129.

Osman, M. M., Hemeda, S. A., Hassanin, A. A. and Husseiny, W. A. 2017. Polymorphism of prolactin gene and its association with egg production trait in four commercial chicken lines. Journal of the Hellenic Veterinary Medical Society, 68, 391-404.

Park, K. S., Shin, H. D., Park, B. L., Cheong, H. S., Cho, Y. M., Lee, H. K., Lee, J.-Y., Lee, J.-K., Oh, B. and Kimm, K. 2006. Polymorphisms in the leptin receptor (LEPR) putative association with obesity and T2DM. Journal of Human Genetics, 51, 85-91.

Peakall, R. and Smouse, P. E. 2012. GenAlEx 6.5: genetic analysis in Excel. population genetic software for teaching and research an update. Bioinformatics, 28, 2537-2539.

Pertille, F., Moreira, G. C. M., Zanella, R., Da Silva Nunes, J. D. R., Boschiero, C., Rovadoscki, G. A., Mourão, G. B., Ledur, M. C. and Coutinho, L. L. 2017. Genome-wide association study for performance traits in chickens using genotype by sequencing approach. Scientific Reports, 7, 41748. doi: 10.1038/srep41748..
Psifidi, A., Banos, G., Matika, O., Desta, T. T., Bettridge, J., Hume, D. A., Dessie, T., Christley, R., Wigley, P. and Hanotte, O. 2016. Genomewide association studies of immune, disease and production traits in indigenous chicken ecotypes. Genetics Selection Evolution, 48, 74-90.

Purcell, S., Neale, B., Todd-Brown, K., Thomas, L., Ferreira, M. A., Bender, D., Maller, J., Sklar, P., De Bakker, P. I. and Daly, M. J. 2007. PLINK: a tool set for whole-genome association and population-based linkage analyses. The American Journal of Human Genetics, 81, 559575.

Qiu, F., Nie, Q., Luo, C., Zhang, D., Lin, S. and Zhang, X. 2006. Association of single nucleotide polymorphisms of the insulin gene with chicken early growth and fat deposition. Poultry Science, 85, 980-985.

Qu, L., Shen, M., Guo, J., Wang, X., Dou, T., Hu, Y., Li, Y., Ma, M., Wang, K. and Liu, H. 2019. Identification of potential genomic regions and candidate genes for egg albumen quality by a genome-wide association study. Archives Animal Breeding, 62, 113-123.

Raymond, M. 1995. GENEPOP (version 1.2): population genetics software for exact tests and ecumenicism. J. Hered., 86, 248-249.

Rikimaru, K., Komatsu, M., Suzuki, K., Uemoto, Y., Takeda, H. and Takahashi, H. 2012. Association between cholecystokinin type A receptor haplotypes and growth traits in Japanese Hinai-dori crossbred chickens. Molecular Biology Reports, 39, 4479-4484.

Sadeyen, J.R., Trotereau, J., Protais, J., Beaumont, C., Sellier, N., Salvat, G., Velge, P. and Lalmanach, A.-C. 2006. Salmonella carrier-state in hens: study of host resistance by a gene expression approach. Microbes and Infection, 8, 1308-1314.

Saleh, M.S. 2019. Using bioinformatics SNP to improve immune genetic response against some pathogens in poultry. M Sc. Thesis In cooperation between Faculty of Agriculture at Moshtohor, Benha University, Egypt and Tempus European Union program 2019.

Saleh, M. S., Iraqi, M. M., Khalil, M. H., and Camarda, A. 2020a. Crossbreeding analyses and polymorphic associations of gallinacin genes with growth traits in chickens. Livestock Science, 240, 104118. doi:10.1016/j.livsci.2020.104118

Saleh, M. S., Khalil, M. H., Iraqi, M. M., and Camarda, A. 2020b. Polymorphic characterization of gallinacin candidate genes and their molecular associations with growth and immunity traits in chickens. British Poultry Science, 62:2, 180187 doi:10.1080/00071668.2020.1847252

Saleh, M. S., Khalil, M. H., Iraqi, M. M., and Camarda, A. 2020c. Molecular associations of gallinacin genes with immune response against 
Salmonella typhimurium in chickens, Livestock Science, 244, doi: https://doi.org/10.1016/j.livsci.2020.104315

Sasaki, O., Odawara, S., Takahashi, H., Nirasawa, K., Oyamada, Y., Yamamoto, R., Ishii, K., Nagamine, Y., Takeda, H., Kobayashi, E. and Furukawa, T., 2004. Genetic mapping of quantitative trait loci affecting body weight, egg character and egg production in F2 intercross chickens. Animal Genetics, 35(3): 188-194.

Seo, D., Yun, J., Kang, W., Jeon, G., Hong, K. C. and Ko, Y. 2001. Association of insulin-like growth factor-I (IGF-I) gene polymorphism with serum IGF-I concentration and body weight in Korean Native Ogol chicken. Asian-Australasian Journal of Animal Sciences, 14, 915-921.

Seo, J., Oh, J. D., Choi, E. J., Lim, H. K., Seong, J., Song, K. D., Lee, J. H., Lee, H. K., Kong, H. S. and Jeon, G. J. 2013. Effects of SNP in TSH- $\beta$ Gene of Chicken on Economic Traits. Korean Journal of Poultry Science, 40, 115-120.

Sewalem, A., Morrice, D.M., Law, A., Windsor, D., Haley, C.S., Ikeobi, C.O.N., Burt, D.W. And Hocking, P.M. 2002. Mapping of quantitative trait loci for body weight at three, six, and nine weeks of age in a broiler layer cross. Poultry Science, 81, 1775-1781.

Siwek, M., Cornelissen, S. J., Buitenhuis, A. J., Nieuwland, M. G., Bovenhuis, H., Crooijmans, R. P., Groenen, M. A., Parmentier, H. K. and van der Poel, J. J. 2004. Quantitative trait loci for body weight in layers differ from quantitative trait loci specific for antibody responses to sheep red blood cells. Poultry Science, 83:853-859.

Sun, C., Qu, L., Yi, G., Yuan, J., Duan, Z., Shen, M., Qu, L., Xu, G., Wang, K. \& Yang, N. 2015. Genome-wide association study revealed a promising region and candidate genes for eggshell quality in an $\mathrm{F} 2$ resource population. $B M C$ Genomics, 16, 565-579.

Su, Y.J., Shu, J.T., Zhang, M., Zhang, X.Y., Shan, Y.J., Li, G.H., et al. 2014. Association of chicken growth hormone polymorphisms with egg production. The Genetics and Molecular Research Journal, 13(3):4893-4903.

Tatsuda, K. and Fujinaka, K. 2001. Genetic mapping of the QTL affecting body weight in chickens using a F2 family. British Poultry Science, 42(3):333-337.

Tempfli, K., Konrád, S., Kovácsné Gaál, K., Pongrácz, L. and Bali Papp, Á. 2015. Prolactin, dopamine receptor D1 and Spot14apolymorphisms affect production traits of Hungarian Yellow hens. Livestock Science, 174, 26-

30.https://doi.org/10.1016/j.livsci.2015.01.012.

Tohidi, R., Idris, I., Malar Panandam, J. and Hair Bejo, M. 2013. The effects of polymorphisms in 7 candidate genes on resistance to Salmonella
Enteritidis in native chickens. Poultry Science, 92, 900-909.

Tuiskula-Haavisto M., Honkatukia M., Vilkki J., de Koning D.J, Schulman N.F. and MakiTanila A. 2002. Mapping of quantitative trait loci affecting quality and production traits in egg layers. Poultry Science 81, 919-27.

Tyasi, T. L., Qin, N., Liu, D., Niu, X., Zhu, H. and $\mathrm{Xu}, \mathbf{R}$. 2018. The association between novel polymorphisms of gremlin genes and egg-laying performance traits in Chinese village Dagu hens. Annals of Animal Science, 18, 361-373.

Twito, T., Weigend, S., Blum, S., Granevitze, Z., Feldman, M., Perl-Treves, R., Lavi, U. and Hillel, J. 2007. Biodiversity of 20 chicken breeds assessed by SNPs located in gene regions. Cytogenetic and Genome Research, 117, 319-326.

Uemoto, Y., Sato, S., Ohtake, T., Sato, S., Okumura, Y. and Kobayashi, E. 2011. Ornithine decarboxylase gene is a positional candidate gene affecting growth and carcass traits in F2 intercross chickens. Poultry Science, 90, 35-41.

Vu, C.T. and Ngu, NT. 2016. Single nucleotide polymorphisms in candidate genes associated with egg production traits in native Noi chicken of Vietnam. International Journal of Plant, Animal and Environmental Sciences, 6(1):162-169.

Wei, L., Fangqun, L. and Daquan, L. 2009. IGF-1 Gene polymorphism and weight-related analysis. Int. J Biol., 1, 113-118.

Weigend, S. 2004. Overview on the use of molecular markers to characterise genetic diversity in chickens. World's Poultry Congress and Exhibition. In: Proceedings of XXII World's Poultry Congress, 8-13 June 2004, 192. Istanbul, Turkey.

Xu, H., Zeng, H., Luo, C., Zhang, D., Wang, Q., Sun, L., Yang, L., Zhou, M., Nie, Q. and Zhang, X. 2011a. Genetic effects of polymorphisms in candidate gens and the QTL region on chicken age at first egg. BMC Genetics 12:33. doi: 10.1186/1471-2156-12-33.

Xu, H., Zeng, H., Zhang, D., Jia, X., Luo, C., Fang, M., Nie, Q. and Zhang, $X$. 2011b. Polymorphisms associated with egg number at 300 days of age in chickens. Genetics and Molecular Research, 10: 2279-2289.

Xu, Z., Nie, Q. and Zhang, X. 2013. Overview of genomic insights into chicken growth traits based on genome-wide association study and microRNA regulation. Current Genomics, 14, 137-146.

Yang, ZJ., Fu, L., Zhang, GW., Yang, Y., Chen, SY., Wang, J. and Lai, S.J. 2013. Identification and association of SNPs in TBC1D1 gene with growth traits in two rabbit breeds. AsianAustralasian Journal of Animal Sciences, 26, 1529-1535.

Ye, X., Avendano, S., Dekkers, J. and Lamont, S. 2006. Association of twelve immune-related genes with performance of three broiler lines in two 
different hygiene environments. Poultry Science, 85, 1555-1569.

Yi, G., Shen, M., Yuan, J., Sun, C., Duan, Z., Qu, L., Dou, T., Ma, M., Lu, J. and Guo, J. 2015. Genome-wide association study dissects genetic architecture underlying longitudinal egg weights in chickens. BMC Genomics, 16, 746-760.

Yi, Z., Li, X., Luo, W., Xu, Z., Ji, C., Zhang, Y., Nie, Q., Zhang, D. and Zhang, X. 2018. Feed conversion ratio, residual feed intake and cholecystokinin type A receptor gene polymorphisms are associated with feed intake and average daily gain in a Chinese local chicken population. Journal of Animal Science and Biotechnology, 9, 50-59.

Yuan, J., Wang, K., Yi, G., Ma, M., Dou, T., Sun, C., Qu, L.-J., Shen, M., Qu, L. and Yang, N. 2015. Genome-wide association studies for feed intake and efficiency in two laying periods of chickens. Genetics Selection Evolution, 47, 82-95.

Yuan, Z., Chen, Y., Chen, Q., Guo, M., Kang, L., Zhu, G. and Jiang, Y., 2016. Characterization of chicken MMP13 expression and genetic effect on egg production traits of its promoter polymorphisms. G3: Genes, Genomes, Genetics, 6(5): 1305-1312.

Yunis, R., Heller, E., Hillel, J. and Cahaner, A. 2002. Microsatellite markers associated with quantitative trait loci controlling antibody response to Escherichia coli and Salmonella enteritidis in young broilers. Animal Genetics, 33, 407-414.

Zhang, Z.R., Liu, Y.P., Yao, Y.G., Jiang, X.S., Du, H.R. and Zhu, Q. 2009. Identification and association of the single nucleotide polymorphisms in calpain3 (CAPN3) gene with carcass traits in chickens. BMC Genetics, 10, 1017.

Zhao, X., Li, M., Xu, S. and Liu, G. 2015. Single nucleotide polymorphisms in IGFBP-2 gene and their associations with body weight traits on Jinghai Yellow chicken. Brazilian Journal of Poultry Science, 17, 497-502.

Zhou, H. and Lamont, S. 2003a. Associations of six candidate genes with antibody response kinetics in hens. Poultry Science, 82, 1118-1126.

Zhou, H. and Lamont, S. J. 2003b. Chicken MHC class I and II gene effects on antibody response kinetics in adult chickens. Immunogenetics, 55, 133-140.

Zhou, H., Buitenhuis, A., Weigend, S. and Lamont, S. 2001. Candidate gene promoter polymorphisms and antibody response kinetics in chickens: interferon- $\gamma$, interleukin-2, and immunoglobulin light chain. Poultry Science, 80, 1679-1689.

Zhou, H., Mitchell, A., Mcmurtry, J., Ashwell, C. And Lamont, S. J. 2005. Insulin-like growth factor-I gene polymorphism associations with growth, body composition, skeleton integrity, and metabolic traits in chickens. Poultry Science, 84, 212-219.

Zhou, M., Du, Y., Nie, Q., Liang, Y., Luo, C., Zeng, H. and Zhang, X. 2010. Associations between polymorphisms in the chicken VIP gene, egg production and broody traits. British Poulttry Science, 51, 195-203.

Zhu, G. and Jiang, Y. 2014. Polymorphism, genetic and association with egg production traits of chicken matrix metalloproteinases 9 promoter. Asian- Australasian Journal of Animal Sciences, 27(11):1526-1531. 